\title{
Phytoplankton ecology of Sechelt Inlet, a fjord system on the British Columbia coast. I. General features of the nano- and microplankton
}

\author{
R. Haigh ${ }^{1}$, F. J. R. Taylor ${ }^{1,2, *}$ T. F. Sutherland ${ }^{3}$ \\ ${ }^{1}$ Department of Oceanography, University of British Columbia, Vancouver, British Columbia, Canada V6T 124 \\ ${ }^{2}$ Department of Botany, University of British Columbia, Vancouver, British Columbia, Canada V6T 1Z4 \\ ${ }^{3}$ Department of Oceanography, Dalhousie University, Halifax, Nova Scotia, Canada B3H 4J1
}

\begin{abstract}
The Sechelt Inlet complex (British Columbia, Canada), including Narrows and Salmon Inlets, was sampled from May 1988 to September 1990 in order to describe the nutrient and plankton regimes. Species succession within the inlet was typical for temperate unpolluted waters despite aquaculture activity and nutrient-loading from the town of Sechelt at the southern end. The N:P ratio in the upper $21 \mathrm{~m}$ of 8.3 , which is well below the Redfield ratio of 16 , suggests an $\mathrm{N}$-limited system. The ratio is also lower than those found in adjacent systems, and supports the assumption that Sechelt Inlet is the least influenced by oceanic waters. The N:P ratio also coincides with the optimum ratio for Skeletonema costatum of 8.1 which suggests that either the system provided an optimal nutrient regime for this diatom or the dominance of S. costatum determined ambient N:P ratios. The spring bloom, dominated by S. costatum and Thalassiosira nordenskjoeldii, occurred early (in March) due to the combined influence of stratification, created by runoff from Salmon Inlet, and shelter from wind exposure. By summer the waters became depleted of nitrate down to $5 \mathrm{~m}$, and nanoplankton, composed chiefly of cryptomonads and Chrysochromulina spp., prevailed. Bimodal peaks in nanoflagellate biomass occurred each summer, with the cryptomonads remaining regular components. Under normal meteorological conditions Chrysochromulina spp. would codominate but during 1989, storm activity in May somehow caused the replacement of the prymnesiomonads by the silicoflagellate Dictyocha speculum. The latter occurred in its askeletal form during the late summer nanoflagellate peak. The water injected through the mouth of Sechelt Inlet by a tidal jet combined with water overlying the anoxic bottom of inner Narrows Inlet and caused stimulation of plankton growth at the confluence of these 2 inlets. There was also high biomass at the shallow southern end possibly due to increased mixing over a sill and mild eutrophication
\end{abstract}

\section{INTRODUCTION}

There is a need for multi-year species-level plankton studies in coastal regions, especially in British Columbia, Canada, where fjords and bays are increasingly used for aquaculture. The environmental departments of the British Columbian and Canadian governments have created and maintained a few plankton databases; however, these time series have large gaps and the samples are often taken at varying locations from year to year. Sancetta (1989) presented a 3 yr time series of diatom flux using sediment traps in Jervis and Saanich

- Addressee for correspondence
Inlets, but the data only reported species which remained intact upon sinking out of the euphotic zone. Buchanan (1966) studied the micro- and nanoplankton of Indian Arm in detail; however, the study only spanned 1 yr which is not sufficient to characterize an inlet. Multi-year series are needed because there is usually significant interannual variability in biomass and species composition. Weather patterns create much of this difference, but there are large-scale cycles on the order of years which also affect the plankton. The most notable pattern on the British Columbian coast is a $7 \mathrm{yr}$ cycle in toxicity records which is thought to be connected with the El-Niño Southern Oscillation (ENSO) event (Gaines \& Taylor 1985) 
Sechelt Inlet (Fig. 1) was chosen for study for several reasons. It is a true fjordic inlet with a shallow sill $(14 \mathrm{~m})$ that restricts the lateral flow of water. The Norwegian model of upper estuarine circulation and bottom water hypoxia characterize this inlet (Lazier 1963) and should affect the phytoplankton populations. Also, Sechelt Inlet experienced increased aquaculture activity over the last decade (15 salmon farms, 12 oyster leases in 1988). Consequently, a plankton study was needed for industry to choose optimal sites: those which balance high productivity and potentially harmful effects due to noxious plankton. This was not done prior to the establishment of farms and there was a loss to the local industry of Can $\$ 2.5$ million (Taylor et al. 1991).

Sechelt Inlet (Fig. 1) is a southern British Columbian fjord located $43 \mathrm{~km}$ northwest of Vancouver. It consists of a main inlet and 2 adjoining ones, Narrows and Salmon Inlets, and is collectively referred to as the Sechelt Inlet complex. The main inlet system is $29 \mathrm{~km}$ long with an average width of $1.2 \mathrm{~km}$ and a maximum depth of $300 \mathrm{~m}$. Hydrographically, Salmon Inlet (19 km)

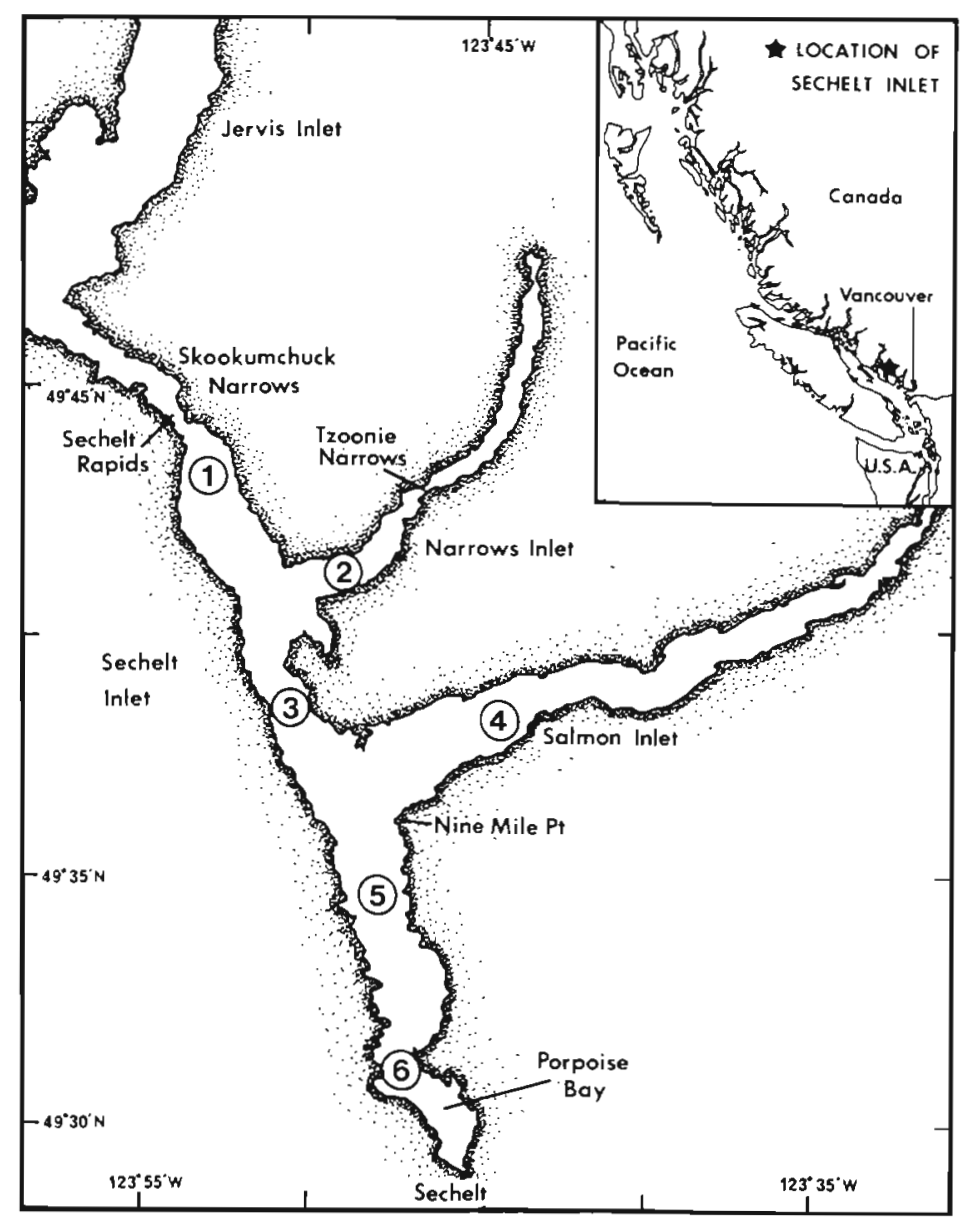

Fig. 1. Sechelt Inlet complex with station locations is not considered a separate side inlet but the head of the main Sechelt Inlet system because there is no sill that separates these 2 regions (Lazier 1963) and the main fresh water inflow is located near its head. The head of the main inlet (between Nine Mile Point and Porpoise Bay) only receives a small amount of fresh water runoff and as a consequence does not contribute significantly to estuarine flow. This area has a shallow shelf and a minor sill. Narrows Inlet $(14 \mathrm{~km})$ is separated from the main inlet system by a shallow sill (11 $\mathrm{m}$ ) at Tzoonie Narrows. The shallow basin (maximum of $85 \mathrm{~m}$ ) that extends past Tzoonie Narrows is ca $8.4 \mathrm{~km}$ long and $0.8 \mathrm{~km}$ wide. Inner Narrows Inlet has periodic anoxic bottom waters (Lazier 1963).

Skookumchuck Narrows, which connects Sechelt Inlet to Jervis Inlet, is constricted and shallow (14 m) at Sechelt Rapids (Pickard 1961). Tidal exchange through Skookumchuck Narrows is predominantly unidirectional at any one time and the tidal flow (maximum $7.5 \mathrm{~m} \mathrm{~s}^{-1}$ ) either enters or leaves the inlet in a turbulent jet (Lazier 1963). Downstream of the sill the 'free' turbulent jet spreads out and expands as the surrounding water is entrained into it. The jet also 'hugs' the bottom topography of the sill and descends into the inlet until buoyancy forces allow the intruding water mass to find a depth layer similar to its density. The upper layer of Sechelt Inlet experiences daily fluctuations in vertical profiles of temperature and dissolved oxygen as a result of internal waves generated at the Skookumchuck sill (Gormican 1989).

Three distinct water layers exist in Sechelt Inlet: a surface layer $(5 \mathrm{~m})$ of low-salinity water (due to precipitation and river runoff) with seasonally high temperatures (due to solar heating); an intermediate layer influenced by the erosion of the tidal jet, occupying a depth between 5 and $65 \mathrm{~m}$; and a deep layer of resident water, characterized by uniform temperature and salinity (Lazier 1963). The dissolved oxygen content of this stagnant deep water can fall below $7 \mathrm{mg} \mathrm{l}^{-1}$ (Lazier 1963, Smethie 1987) and is replaced periodically (S. Pond pers. comm.); upward displacement of low-oxygen water poses a potential threat to fish farms.

Freshwater runoff and precipitation are largely responsible for a 2-layer flow system that drives the estuarine circulation in most fjords. As the brackish surface water flows seaward, a subsurface dense oceanic water mass flows into the estuary to compensate for the loss of surface water. However this estuarine flow depends largely on the properties of the tidal jet and its interaction with the resi- 
dent water of the inlet basin. Estuarine circulation in Sechelt Inlet is slight due to the relatively low freshwater drainage $\left(110 \mathrm{~m}^{3} \mathrm{~s}^{-1}\right.$; Pickard 1961), and will depend largely on a dense intrusion of a tidal jet to flush the indigenous deep water zone (Lazier 1963).

This paper essentially provides an ecological description of Sechelt Inlet and serves as a background for subsequent papers on the distribution and seasonal succession of harmful species and microzooplankton.

\section{MATERIALS AND METHODS}

Field samples were collected from 6 stations in Sechelt Inlet $\left(49^{\circ} 40^{\prime} \mathrm{N}, 123^{\circ} 45^{\prime} \mathrm{W}\right)$ between May 1988 and September 1990 (Fig. 1). Samples were collected at least once a month, and twice a month from June to September. Samples were taken using the Segmented Integrated Pipe Sampler (SIPS; Sutherland et al. 1992). This system is composed of 8 segments of PVC tubing, with an inside diameter of $3.75 \mathrm{~cm}$. The segments are connected by snap-together joints, and contain closing devices at the lower end. The 2 surface tubes are $1.5 \mathrm{~m}$ in length and the remaining 6 tubes are $3.0 \mathrm{~m}$; when the 8 are connected they reach a depth of $21 \mathrm{~m}$. The contents of each segment were released into a mixing chamber for sampling aboard the boat. A sample was also taken from $30 \mathrm{~m}$ with a closing bottle attached to the winch line.

Temperature and salinity of the integrated samples were measured using a thermometer and Endeco refractometer or Guildline Autosal salinometer, respectively. Occasionally, a Guildline CTD was used to obtain in situ temperature and salinity. Chlorophyll samples were obtained by filtering $100 \mathrm{ml}$ of seawater from depth intervals of $0-1.5 \mathrm{~m}, 1.5-3.0 \mathrm{~m}, 3.0-6.0 \mathrm{~m}$, $9.0-12.0 \mathrm{~m}$ and $18.0-21.0 \mathrm{~m}$ through pre-combusted $2.5 \mathrm{~cm}$ glass fibre filters (GF/F, $0.7 \mu \mathrm{m}$ ) and frozen. In the laboratory the filters were placed in $90 \%$ acetone, sonicated in ice water for $20 \mathrm{~min}$, and extracted in the dark for $24 \mathrm{~h}$ at $5^{\circ} \mathrm{C}$. The acetone solution was analyzed for chlorophyll a (chl a) and phaeopigments using a Turner Designs Model 10 fluorometer according to Parsons et al. (1984a). Nutrient samples were collected as for chlorophyll and stored in $30 \mathrm{ml}$ acidwashed Nalgene polypropylene bottles which were immediately placed in the cooler/freezer; no preservatives were added. Nitrate (including nitrite; Wood et al. 1967) and ammonium were later measured on a Technicon AutoAnalyzer. Phosphate was determined using the procedure in Parsons et al. (1984a) and measured on a Bausch and Lomb spectrophotometer.

Representative phytoplankton subsamples (125 ml) were preserved with acidic Lugol's solution (final concentration: $1 \%$ ) and analysed using the Utermöhl technique (Hasle 1978). Depending on biomass, 2.5 to $10 \mathrm{ml}$ were settled in a counting chamber for at least $12 \mathrm{~h}$. Unfortunately, this methodology underestimated the heterotrophic nanoplankton, such as heterotrophic cryptomonads, which would best be distinguished using an epifluorescence technique (Geider 1988). Heterotrophic organisms were identified based solely on morphology and were therefore subject to analyst error Nanoplankton were counted at $500 \times$ along one or two 10 to $20 \mathrm{~mm}$ transects. The more common microplankton species were viewed at $240 \times$ along 6 transects across the chamber diameter (25 to $26 \mathrm{~mm}$ ). Finally, the entire chamber bottom was scanned at $95 x$ for large and/or rare species. The counts were then converted into cells $\mathrm{l}^{-1}$.

The plankton data were integrated over $21 \mathrm{~m}$ and converted to carbon. The conversion required cell volumes specific to each species. Where possible, representative cells were measured for each species and the volume was calculated using equations for simple geometric shapes (spheroids, cylinders, boxes and cones). For a number of the less common species dimensions were extracted from the literature [diatoms: Cupp (1943), Hendey (1964), Rines \& Hargraves (1988); dinoflagellates: Schiller (1933, 1937), Cattell (1969), Dodge (1982); nanoflagellates: Campbell (1973), Throndsen (1988), L. Watanabe (unpubl.)]. Equations converting volume to carbon were found in Strathman (1967) for diatoms, nanoflagellates and dinoflagellates (photosynthetic and heterotrophic); Haigh \& Taylor (1991) for the dinoflagellates Noctiluca and Kofoidinium; and Putt \& Stoecker (1989) for the ciliates (conversion factor includes shrinkage due to Lugol's fixation, though these authors used $2 \%$ vol:vol rather than $1 \%$ ).

\section{RESULTS}

\section{Environmental variables}

Examples of the 3 most representative periods spring bloom, mid-summer, and fall - have been selected to characterize the system's temperaturesalinity regime (Figs. 2 \& 3). Temperature and salinity contour profiles with depth are presented along a transect running from Stn 1 to 6; Stns 2 and 4 reflect inputs to the system from Narrows and Salmon Inlets, respectively. The contouring assumes no small-scale patchiness between stations and serves to illustrate the large-scale (regional) patterns.

During the time of the spring bloom, March, there was an injection of colder water from Jervis Inlet, via the Skookumchuk tidal jet, penetrating at a depth of 10 to $15 \mathrm{~m}$ (Fig. 2A). This intermediate tongue resulted 


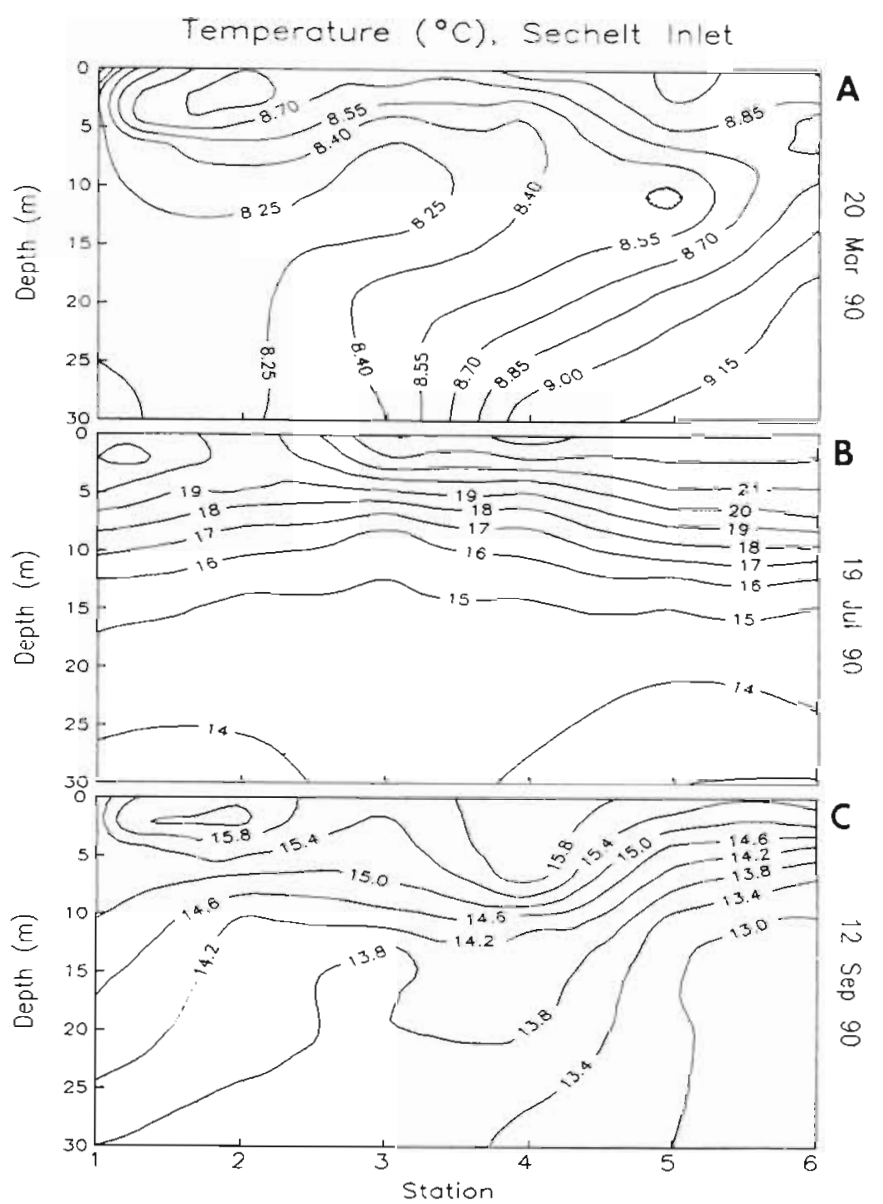

Fig. 2. Contours of temperature $\left({ }^{\circ} \mathrm{C}\right)$ with depth for 3 representative seasons along a transect from Stns 1 to 6 assuming no small-scale patchiness. (A) During the spring bloom, 20 March 1990; (B) during summer stratification, 19 July 1990; (C) during fall, 12 September 1990

in warmer waters at the surface and below $15 \mathrm{~m}$. The water from Jervis Inlet was also more saline (Fig 3A). Generally in spring, the surface waters were 25 to 26 ppt with a lower salinity intrusion from Salmon Inlet. Below $10 \mathrm{~m}$ the salinity was $28 \mathrm{ppt}$.

By mid-summer, the inlet complex experienced warm surface waters, often in excess of $20^{\circ} \mathrm{C}$ (Fig 2B). The stratification was perhaps not apparent in the plots due to the integration of $1.5-3.0 \mathrm{~m}$ of water column when using the SIPS. Salinities had decreased throughout the upper $30 \mathrm{~m}$, with surface values of $\mathrm{ca}$ $20 \mathrm{ppt}$ (Fig. 3B). At times there were marked intrusions of lower salinity water from Narrows Inlet as well as from Salmon Inlet. By fall, water temperatures had dropped due to increased heat loss to the atmosphere. Typically surface waters were $15^{\circ} \mathrm{C}$ (Fig. 2C). Again there were higher salinity intrusions from Jervis Inlet and lower salinity intrusions from the 2 side inlets (Fig. 3C).

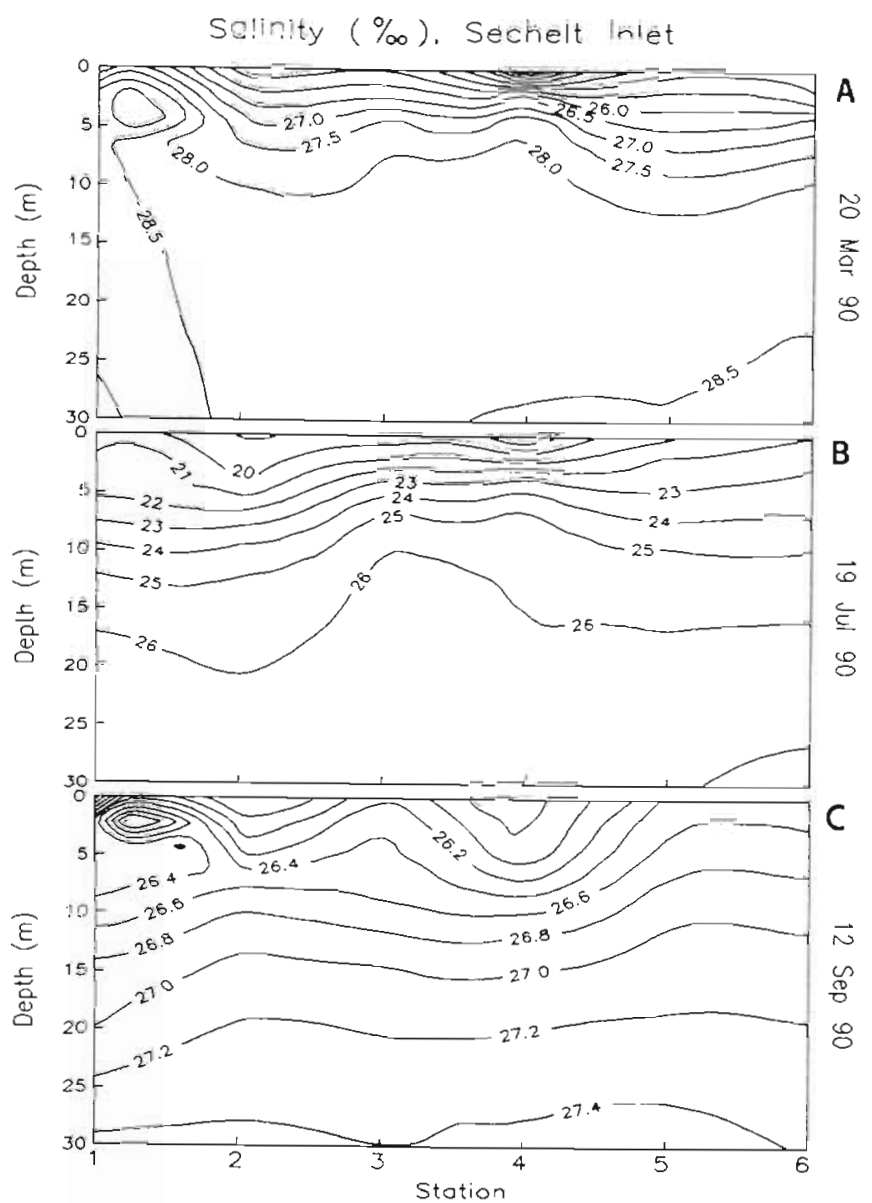

Fig. 3. Contours of salinity (ppt) with depth for 3 representative seasons along a transect from Stns 1 to 6 assuming no small-scale patchiness. (A) During the spring bloom, 20 March 1990; (B) during summer stratification, 19 July 1990; (C) during fall, 12 September 1990

Temporal fluctuations of nitrate and phosphate in the upper $20 \mathrm{~m}$ at Stns 1 and 4 (Fig 4) were selected as representative of the inlet complex. The pattern for Stn 1 was different from those of the other stations due to tidal mixing through Skookumchuk Narrows. Stations 2 to 6 exhibited similar trends; Salmon Inlet (Stn 4) showed the clearest pattern of nutrient impoverishment. The shaded areas in Fig 4 indicate periods when these nutrients were potentially limiting. Nitrate will begin to have limiting effects on the larger species of diatoms once levels fall below $2 \mu \mathrm{M}$ (Eppley et al. 1969) due to factors such as transport limitation (see Pasciak \& Gavis 1974). Phosphate can become limiting at concentrations of $0.2 \mu \mathrm{M}$ (Goldberg et al. 1951, Thomas \& Dodson 1968). There were virtually no times when $\mathrm{PO}_{4}$ was below this expected limiting threshold at Stn 1, due to the tidal mixing, nor at Stns 5 and 6 (not presented), possibly due to seepage from septic tanks in the Porpoise Bay region. The greatest degree of $\mathrm{PO}_{4}$ impoverishment occurred at 
Fig. 4. Macro-nutrient time series in the upper $20 \mathrm{~m}$ for the period May 1988 to September 1990. Nitrate at (A) Stn 1 and (B) Str 4 and phosphate at (C) Stn 1 and (D) Stn 4. Contours are based on a maximum of 5 values (typically from $0-1.5,1.5-3,3-6,9-12$, $18-21 \mathrm{~m})$ at any 1 sampling time
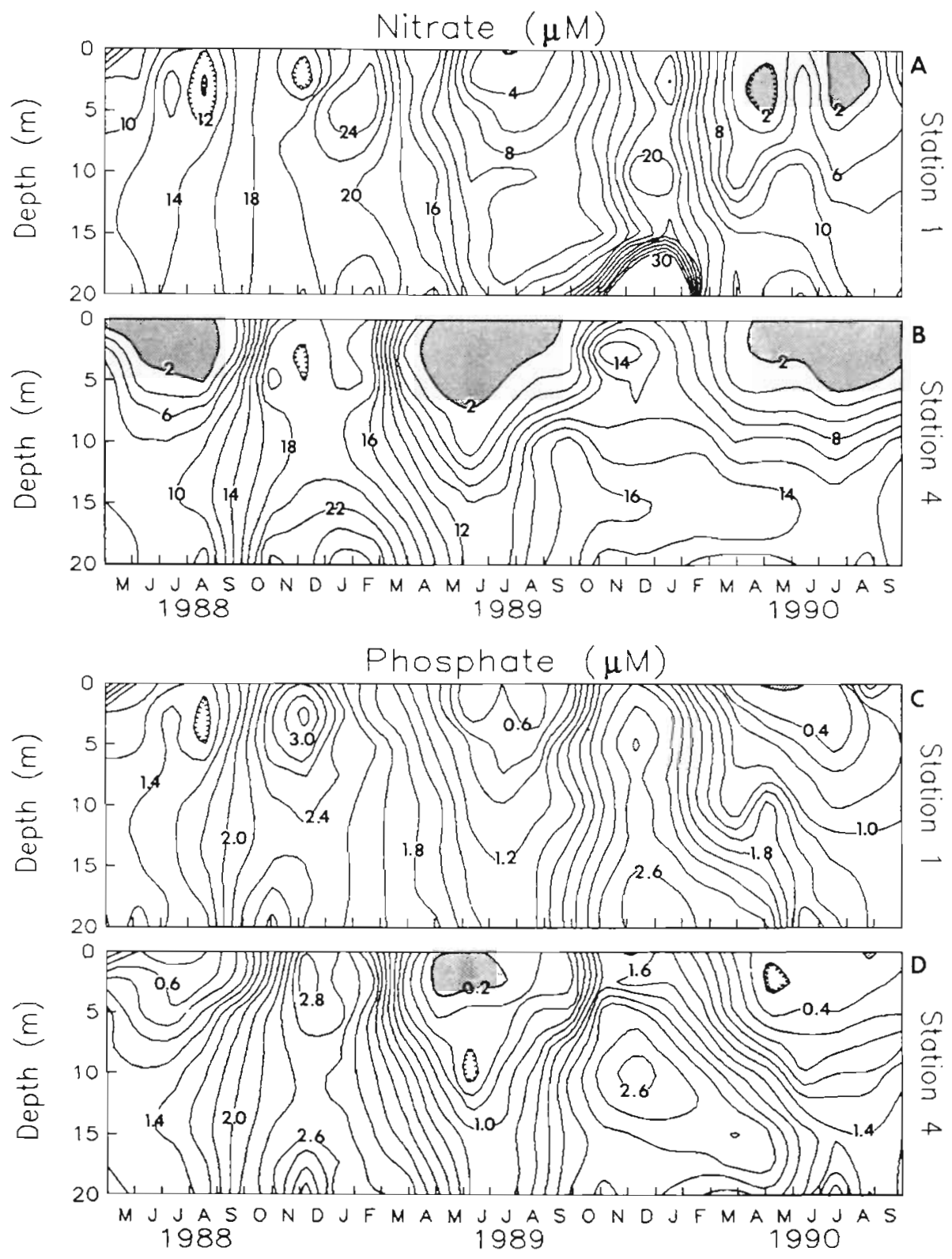

Stn 4 during May and June 1990, extending down to $3 \mathrm{~m}$. The extent of $\mathrm{NO}_{3}$ impoverishment in the system was much greater. At Stn 1 there were a few short periods after the spring bloom and during the summer when $\mathrm{NO}_{3}$ was low. Most of the other stations experienced prolonged, continuous periods of low $\mathrm{NO}_{3}$ down to $5 \mathrm{~m}$ during the summer.

Dissolved nitrogen (nitrate, nitrite, plus ammonium) was correlated to dissolved phosphorus (represented by phosphate) using the data from May 1988, to September 1990 , in the upper $21 \mathrm{~m}$. The $\mathrm{N}$ : P ratios for each station were calculated as the slope of the line of best-fit (Stn 1: $\mathrm{N}: \mathrm{P}=8.5, \mathrm{n}=144$, adj. $\mathrm{r}^{2}=0.73 ;$ Stn $2: \mathrm{N}: \mathrm{P}=8.2$, $\mathrm{n}=141$, adj. $\mathrm{r}^{2}=0.76 ;$ Stn $3: \mathrm{N}: \mathrm{P}=9.2, \mathrm{n}=144$, adj. $r^{2}=0.83 ; \operatorname{Stn} 4: N: P=8.8, n=124$, adj. $r^{2}=0.85 ;$ Stn $5:$
$\mathrm{N}: \mathrm{P}=8.7, \mathrm{n}=137$, adj. $\mathrm{r}^{2}=0.83 ;$ Stn $6: \mathrm{N}: \mathrm{P}=8.8$, $\mathrm{n}=140$, adj. $\mathrm{r}^{2}=0.83$ ). The $\mathrm{N}$ : $\mathrm{P}$ ratio in surface waters $(0-3 \mathrm{~m})$ was plotted as a function of time for each station (Fig. 5) and fluctuated around a value of 8 , which is also the optimum ratio for Skeletonema costatum based on cellular requirements (Sakshaug et al. 1983); the temporal distribution of $S$. costatum biomass in surface waters is also presented (Fig. 5).

Nitrate values were plotted against phosphate for Sechelt Inlet and adjacent regions (Fig. 6) for comparative purposes (ammonium values were not universally available). Data for Sechelt Inlet were taken from all 6 stations down to $21 \mathrm{~m}$; data for Jervis and Saanich. Inlets were made available by S.E. Calvert, Dept of Oceanography, Univ. of British Columbia, for the years 


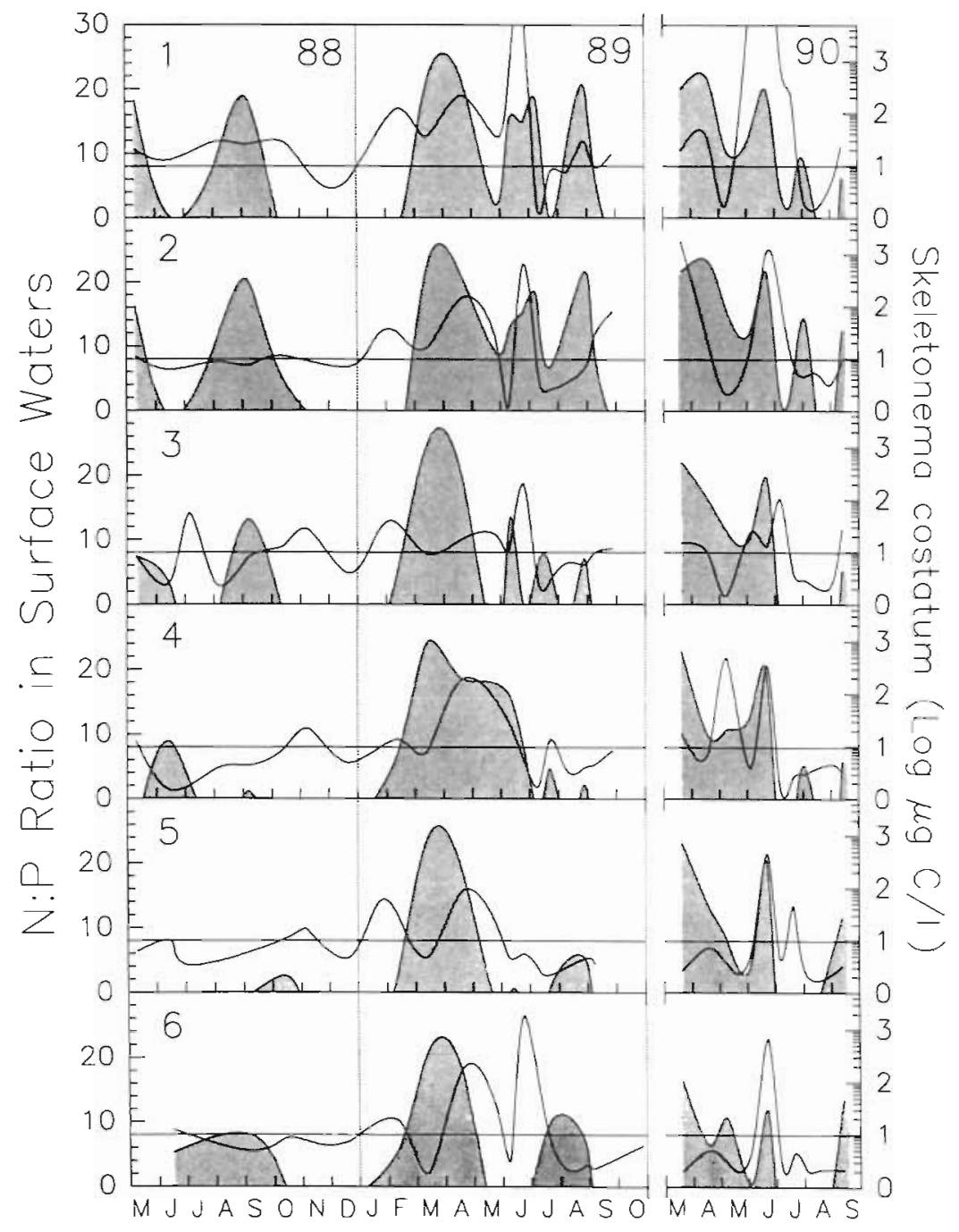

Fig. 5. Nitrogen : phosphorus ratio in surface waters $(0-3 \mathrm{~m})$ at each station from May 1988 to September 1990. Shaded area is the common log of biomass ( $\mu \mathrm{g} \mathrm{C}^{-1}$ ) of Skeletonema costatum in surface waters $(0-3 \mathrm{~m})$. Dashed line at $\mathrm{N}: \mathrm{P}=8$ is the optimum ratio for $S$. costatum; above the line $S$. costatum is potentially P-limited, below the line it is potentially $\mathrm{N}$-limited ceros, and Thalassiosira, and the photosynthetic nanoflagellates. Because the successional pattern of these groups was similar for each station in the Sechelt Inlet complex (indicative of large-scale driving forces such as irradiance), the integrated carbon values for each station were averaged to derive a general successional trend (Fig. 8). Annually, there were 2 distinct blooms: spring and autumn. The spring bloom began in March and was dominated in terms of biomass by the diatoms S. costatum and Thalassiosira spp. (chiefly $T$. nordenskioeldii). The autumn bloom, dominated by Chaetoceros spp. (C. radicans, C. compressum, C. debile, $C$. affine, $C$. constrictum, C. curvisetum), usually started in late August, early September. S. costatum virtually disappeared from the upper 21 m during December and, occasionally, during July/August. The summer period was dominated by nanoflagellates which tended to form background biomass levels of $10^{5}$ to $10^{6} \mu \mathrm{g} \mathrm{C} \mathrm{m} \mathrm{C}^{-2}$.

The successional sequence of the major groups in Sechelt Inlet was typical for temperate coastal waters. Despite meteorological variation the seasonal temperature stratification had been disrupted during May 1989, associated with storm activity), the domination in summer of nanoplankton (flagellates and small centric diatoms) remained constant in 1989 and 1990. Large ciliate populations, reaching 40000 cells $1^{-1}$, were concomitant with nanoflagellates over the summer period.

1988-1989 in the upper $20 \mathrm{~m}_{i}$ and data for the southern Strait of Georgia were found in Clifford et al. (1991) for the year 1990 in the upper $15 \mathrm{~m}$.

At the time of sampling the spring bloom of March 1990, the chl a was concentrated at the southern end of Sechelt Inlet near the junction with Salmon Inlet (Fig. 7A). Freshwater input, especially from Salmon Inlet (Fig. 3A), created density differentials within the inlet of $3 \sigma_{t}$ in the upper $5 \mathrm{~m}$ (Fig. 7B)

\section{Nano- and microplankton}

The chief successional groups in temperate coastal waters are the diatom genera Skeletonema, Chaeto-
The 8 biomass dominants for the system reached a spring peak of $20 \mathrm{~g} \mathrm{C} \mathrm{m}^{-2}$ in 1989 and $10 \mathrm{~g} \mathrm{C} \mathrm{m}^{-2}$ in 1990 (Fig. 9, nanoflagellates were not counted prior to April 1989). Skeletonema costatum and Thalassiosira nordenskioeldii were predominant and codominant during the spring blooms of 1989 and 1990 (by biomass, though $S$. costatum had a much higher cell concentration of the two). Following the spring bloom 2 smaller biomass peaks occurred in early and late summer in both years. The minor peaks consisted of mixed diatom assemblages ( $S$. costatum, $T$ nordenskioeldii, $T$. rotula, Chaetoceros compressum) along with the 2 chief nanoflagellate groups: cryptomonads and Chrysochromulina spp. The second minor peak usually had a significant contribution from the diatom 


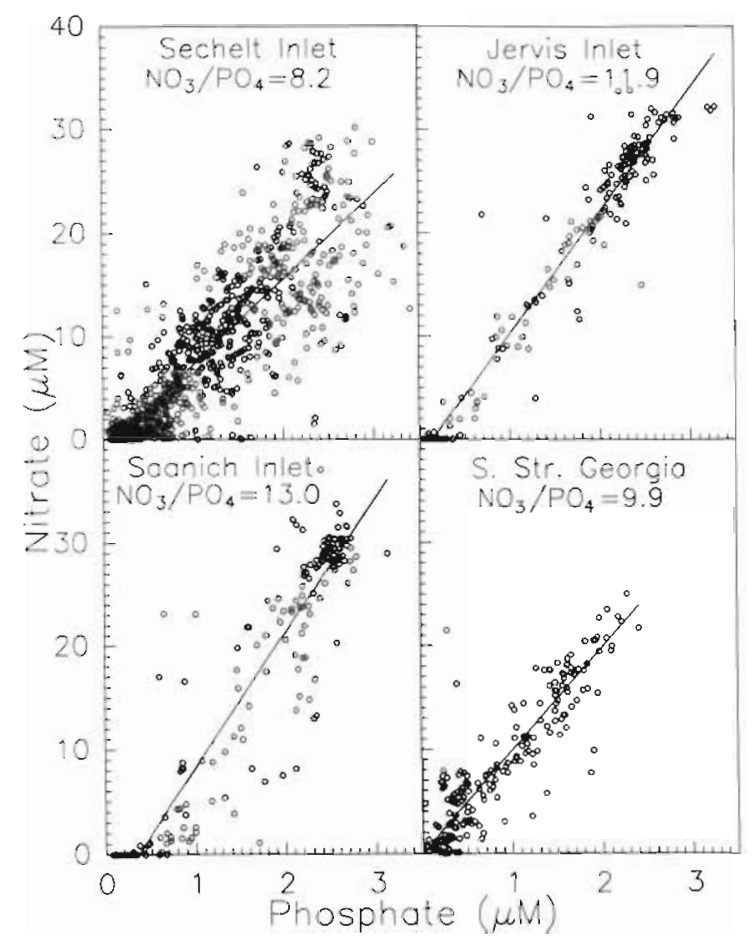

Fig. 6. Nitrate versus phosphate for regions on the southwestern British Columbia coast

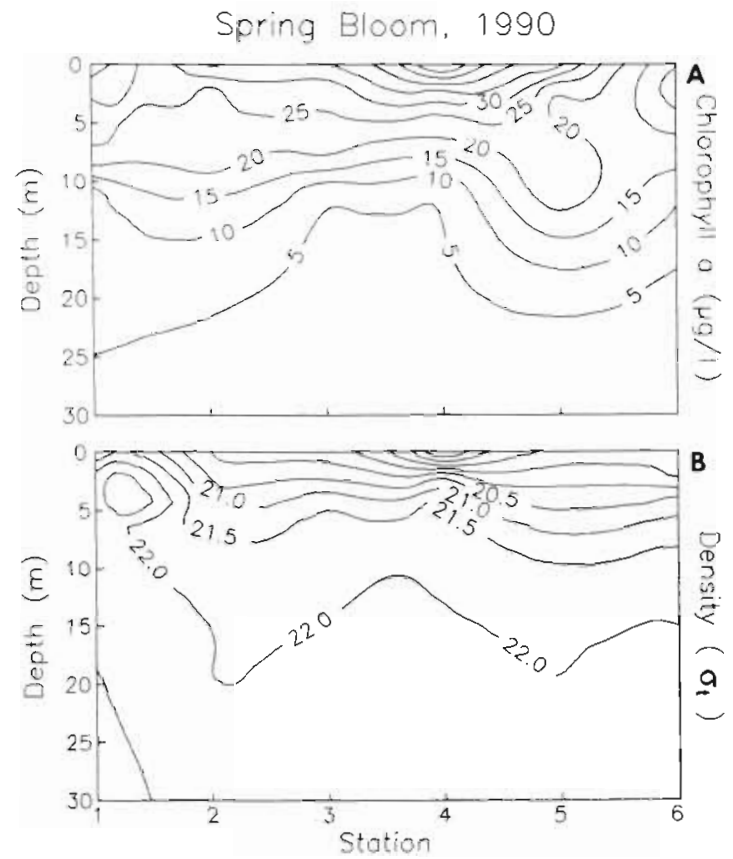

Fig. 7. Spring bloom, March 1990. (A) Contours of chlorophyll a $\left(\mu \mathrm{g} \mathrm{l}^{-1}\right)$ with depth along a transect from Stns 1 to 6 assuming no small-scale patchiness. (B) Contours of density $\left(\sigma_{t}\right)$ with depth along the same transect assuming no small-scale patchiness
Fig. 8. Seasonal succession of 3 chief diatom genera (Skeletonema, Thalassiosira, and Chaetoceros) and the photosynthetic nanoflagellates (predominantly cryptomonads and Chrysochromulina spp.) from May 1988 to September 1990, expressed as the common log of the mean areal biomass (integrated over $21 \mathrm{~m}$ ) of 6 stations. The nanoflagellates were not discriminated until April 1989

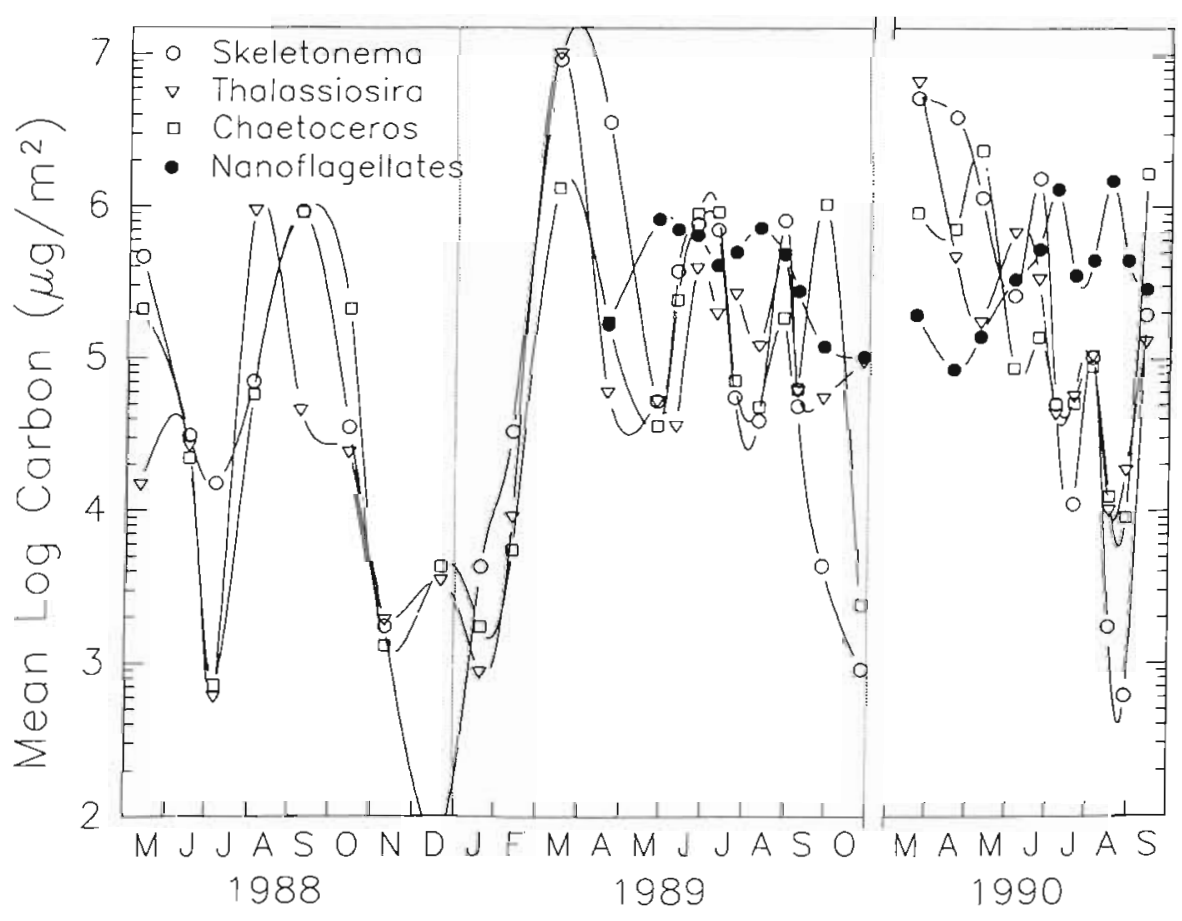

The 8 diatom biomass dominants exclusive of Skeletonema costatum and Thalassiosira nordenskioeldii, which dominated the biomass, reached peaks in excess

of $3.0 \mathrm{~g} \mathrm{C} \mathrm{m}^{-2}$ during 1989. The spring bloom of 1989
Corethron criophilum. Interannual variability is evident in the minor peaks, diatoms becoming decreasingly prevalent from 1988 to 1990 . The nanoflagellates exhibited a reverse trend from 1989 to 1990. 


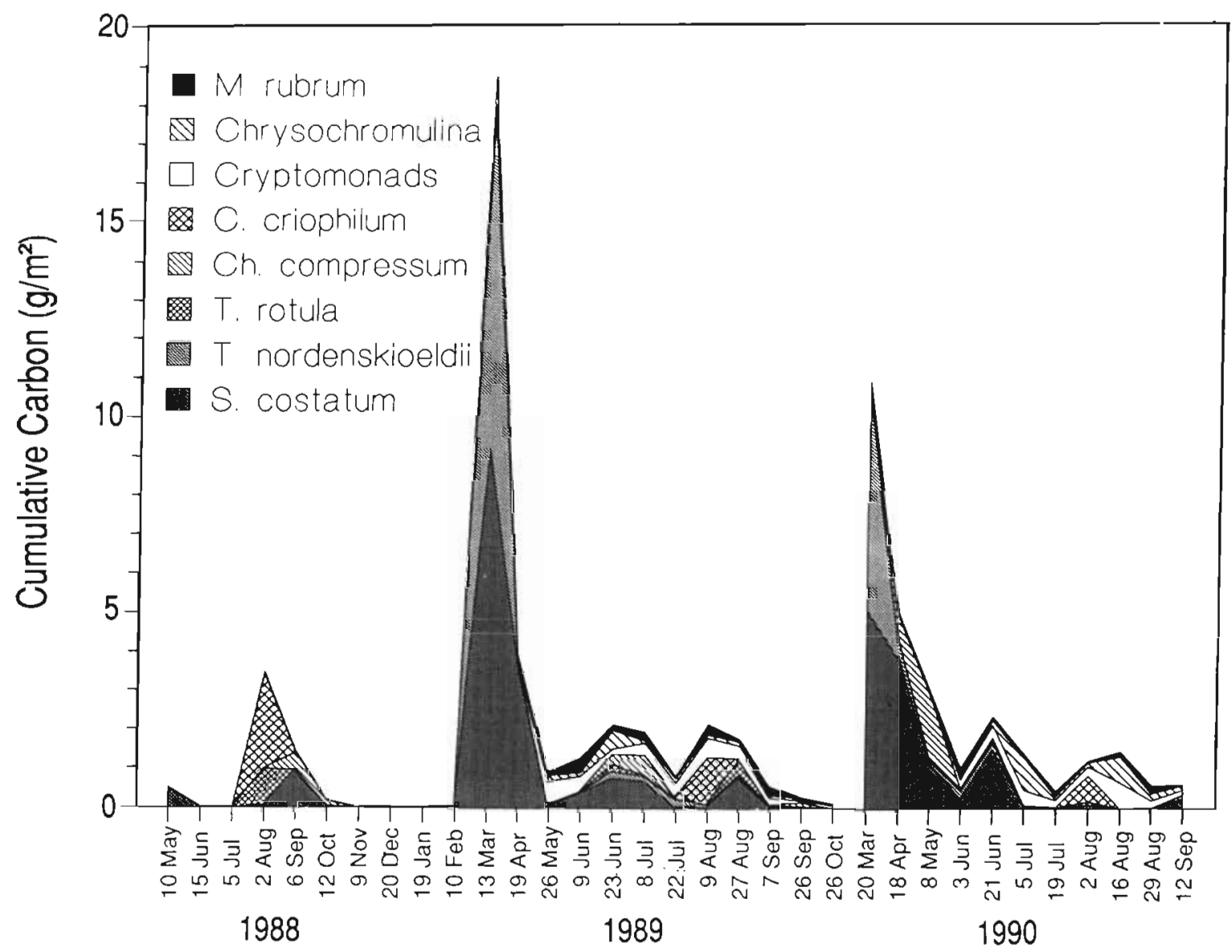

Fig. 9. Cumulative biomass ( $\mathrm{g} \mathrm{C}^{-2}$ ) time series of the 8 most dominant plankters in the Sechelt Inlet system from May 1988 to September 1990. Cryptomonads and Chrysochromulina spp. were not discriminated until April 1989. M.: Mesodinium; C.: Corethron; Ch.: Chaetoceros; T.. Thalassiosira; S.: Skeletonema

was also composed of $T$. decipiens (possibly $T$. aestivalis mistakenly identified), T. rotula, Chaetoceros debile, and C. compressum. In 1990 the other major bloom diatoms were $T$. destivalis, $T$. rotula, and $C$. debile. $C$. compressum did not become numerous until after the main bloom. The composition of dominant spring bloom diatoms in Sechelt Inlet remained constant over these 2 years, and only varied in magnitude.

Peaks in diatom biomass occurred in August/ September (Fig. 10) with 1 minor peak during June/ July 1989, possibly a response to stormy weather in May. The late summer/early fall peaks were initially dominated by Corethron criophilum, which occurred regularly at the beginning of August in each year, decreasing in biomass from 1988 to 1990. Thalassiosira rotula and Ditylum brightwellii were usually associated with C. criophilum. By September these diatoms had been replaced by Chaetoceros species and Leptocylindrus danicus.

The autotrophic ciliate Mesodinium rubrum had a higher average biomass over the study period than did any of the photosynthetic dinoflagellates (Fig. 11), and was most abundant during 1989. It tended to reach maximal biomass in June, a time when the dinoflagellates were sparse. Heterocapsa triquetra appeared in May after the spring bloom, but it was not until mid-July, early-August that the photosynthetic dinoflagellates significantly contributed biomass to the system. The late-summer assemblage was dominated by Goniodoma pseudogonyaulax, Protoceratium reticulatum (syn: Gonyaulax grindleyi), and Ceratium fusus. In September 1989, there was a major bloom of the toxic species Alexandrium catenella which coincided with saxitoxin levels of $32000 \mu \mathrm{g}$ per $100 \mathrm{~g}$ shellfish at Nine Mile Point (Anon. 1989), between Stns 4 and 5. Small gymnodinoids $(<25 \mu \mathrm{m})$ and thecate dinoflagellates $(<25 \mu \mathrm{m})$ predominated during winter.

The 8 dominant nanoflagellate categories exhibited bimodal peaks in biomass each summer (Fig. 12), reaching $1.0 \mathrm{~g} \mathrm{C} \mathrm{m}^{-2}$ in 1989 and $1.5 \mathrm{~g} \mathrm{C} \mathrm{m}^{-2}$ in 1990. During the summer the cryptomonads maintained biomass levels of 0.2 to $0.5 \mathrm{~g} \mathrm{C} \mathrm{m}^{-2}$. In 1990 Chrysochromulina 


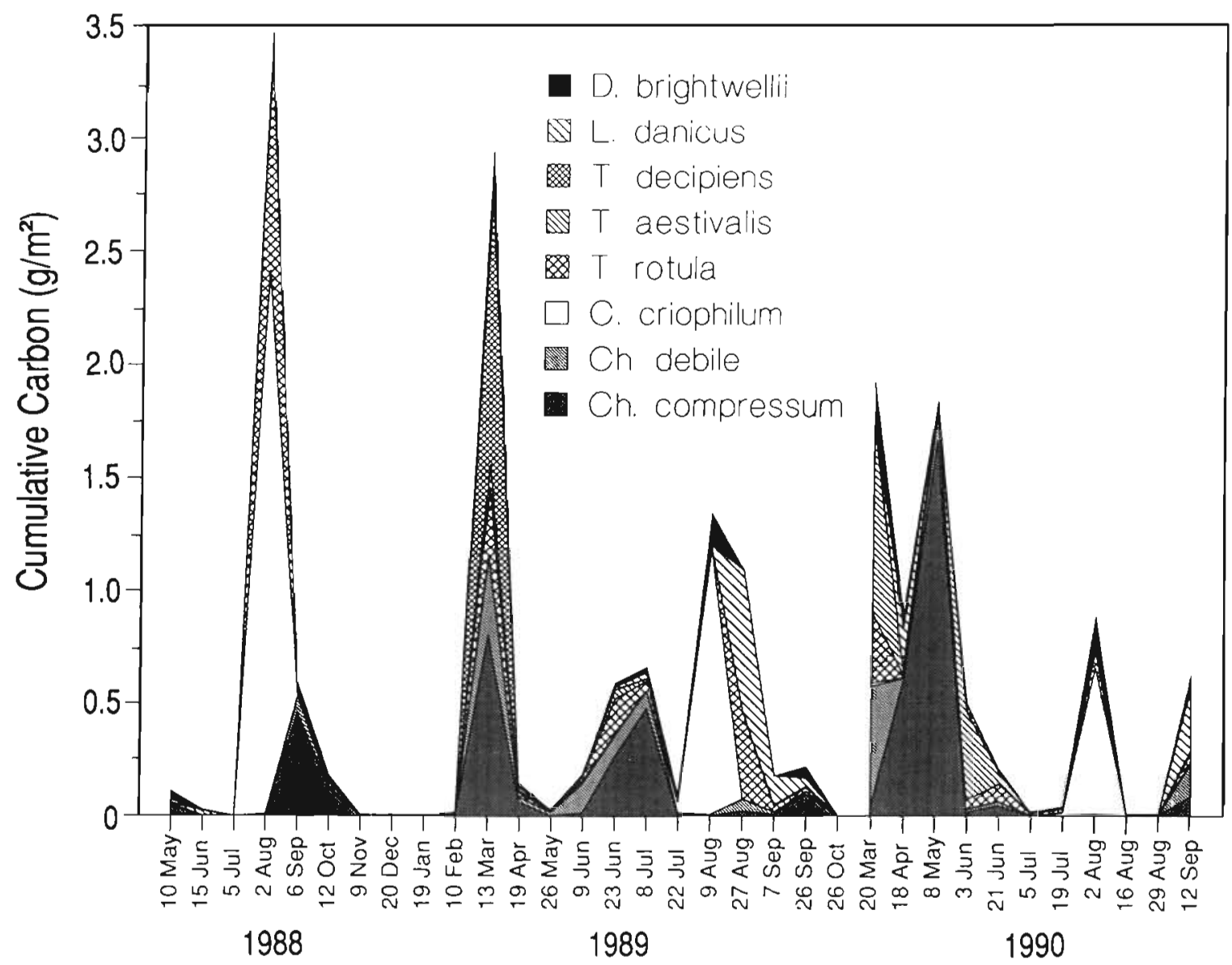

Fig. 10. Cumulative biomass ( $\mathrm{g} \mathrm{C} \mathrm{m}^{-2}$ ) time series of the 8 most dominant diatoms in the Sechelt Inlet system, exclusive of Skeletonema costatum and Thalassiosira nordenskioeldii, from May 1988 to September 1990. D.: Ditylum; L.: Leptocylindrus; T.: Thalassiosira; C.: Corethron; Ch.: Chaetoceros

spp. dominated the remaining nanoflagellate biomass together with the fish-killing chloromonad flagellate Heterosigma carterae (formerly H. akashiwo, see Taylor 1992). During the previous summer the silicoflagellate Dictyocha speculum had virtually displaced Chrysochromulina at the time of the bimodal peaks. The askeletal form of $D$. speculum prevailed over the skeletal form during the second 1989 nanoflagellate peak.

The 7 dominant microheterotrophs collectively accounted for 0.4 to $0.5 \mathrm{~g} \mathrm{C} \mathrm{m}^{-2}$ at their peaks (Fig. 13). Of this group the aloricate oligotrichous ciliates were predominant except during the spring bloom when the dinoflagellate Gyrodinium spirale prevailed. There is an apparent periodicity in the ciliate data with all size categories fluctuating in tandem. The dinoflagellates Protoperidinium depressum and $P$. conicum, which prey on diatoms (Gaines \& Taylor 1984), occurred during the spring bloom and then periodically throughout summer. The heterotrophic silicoflagellate Ebria tripartita occurred throughout summer and was more abundant during 1989 .
The average (over 1989 and 1990) integrated biomass (over $21 \mathrm{~m}$ ) of nano- and microplankton biomass, plotted along the inlet axis from Stns 1 to 6 (Fig. 14), was partitioned into major groups - diatoms, photosynthetic dinoflagellates, photosynthetic microflagellates (chiefly Heterosigma carterae and Dictyocha speculum), photosynthetic nanoflagellates and the heterotrophic protists - to assess their relative contributions. The data were divided into 4 seasonal periods based on plankton composition and stratification in Sechelt Inlet: spring bloom (March), late-spring, earlysummer (April-June), mid-summer (July-August), and fall (September-October). The first trend to note is the seasonal decline in total biomass from spring to fall. Secondly, the distribution of maximum biomass within the inlet shifts from near the lower end (Stn 5) during the spring bloom of diatoms to the junction of Narrows and Sechelt Inlets (Stn 2), in late-spring and earlysummer, where diatoms continued their dominance. By mid-summer Stn 2 experience elevated biomass levels of all groups. Also during summer, there was a 


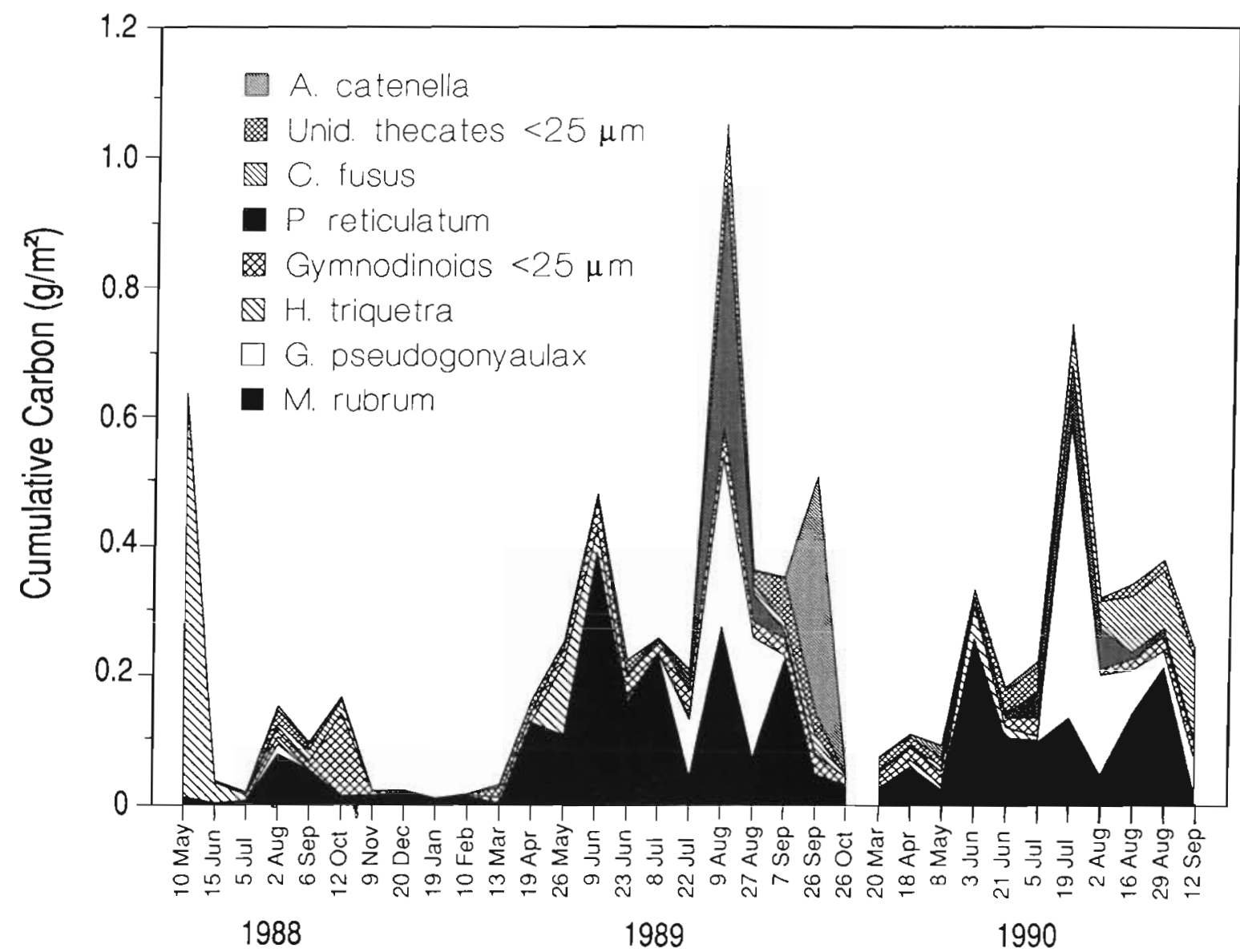

Fig. 11. Cumulative biomass ( $\mathrm{g} \mathrm{C} \mathrm{m}^{-2}$ ) time series of Mesodinium rubrum and the 7 most dominant photosynthetic dinoflagellates in the Sechelt Inlet system from May 1988 to September 1990. A.: Alexanrium; Unid: unidentified; C.: Ceratium $;$ P.: Protoceratium; H.: Heterocapsa; G.: Goniodoma; M.: Mesodinium

rise of biomass at the extreme southern end (Stn 6), due equally to diatoms and nanoflagellates. In autumn, the southern end had the greatest biomass due to the fall bloom of diatoms (predominantly Chaetoceros spp.).

The photoautotrophic biomass was greater than that of the heterotrophs at virtually all times, mostly due to diatoms in the spring and fall and to nanoplankton (both flagellates and small centric diatoms) during summer There were times, however, when the ratio of heterotrophic to photoautotrophic biomass was greater than $50 \%$ (Fig. 15).

\section{DISCUSSION}

The Sechelt Inlet system proved to be a dynamic and variable system. Despite its small size (compared to other British Columbia fjords) there was discernible heterogeneity of biomass, and to a lesser extent, species composition due to physically different environments within the complex. The mouth of Sechelt
Inlet experiences daily turbulence from a tidal jet which injects nutrients via mixing and entrainment. The effect of this jet on plankton biomass was most pronounced at the junction of Narrows and Sechelt Inlets. A similar phenomenon was observed by Parsons et al. $(1984 \mathrm{~b})$ on the outer side of Skookumchuk Narrows. The middle of Sechelt Inlet has the deepest water and is least affected by inputs (nutrients, fresh water, etc.) to the system; it also experienced the lowest year-round biomass levels. Salmon Inlet generally supported low biomass but had a great influence on the system in spring by introducing fresh water, stratifying the upper 5 to $10 \mathrm{~m}$ sufficiently to promote an early spring bloom. The head of the main axis of Sechelt Inlet (Porpoise Bay region) is shallower than most of the system and proved to be an area of high biomass.

The species composition of this system was typical for inlets in temperate regions; however, there were local differences (F. J. R. Taylor et al. unpubl.). The inlet is effectively isolated from oceanic waters and 


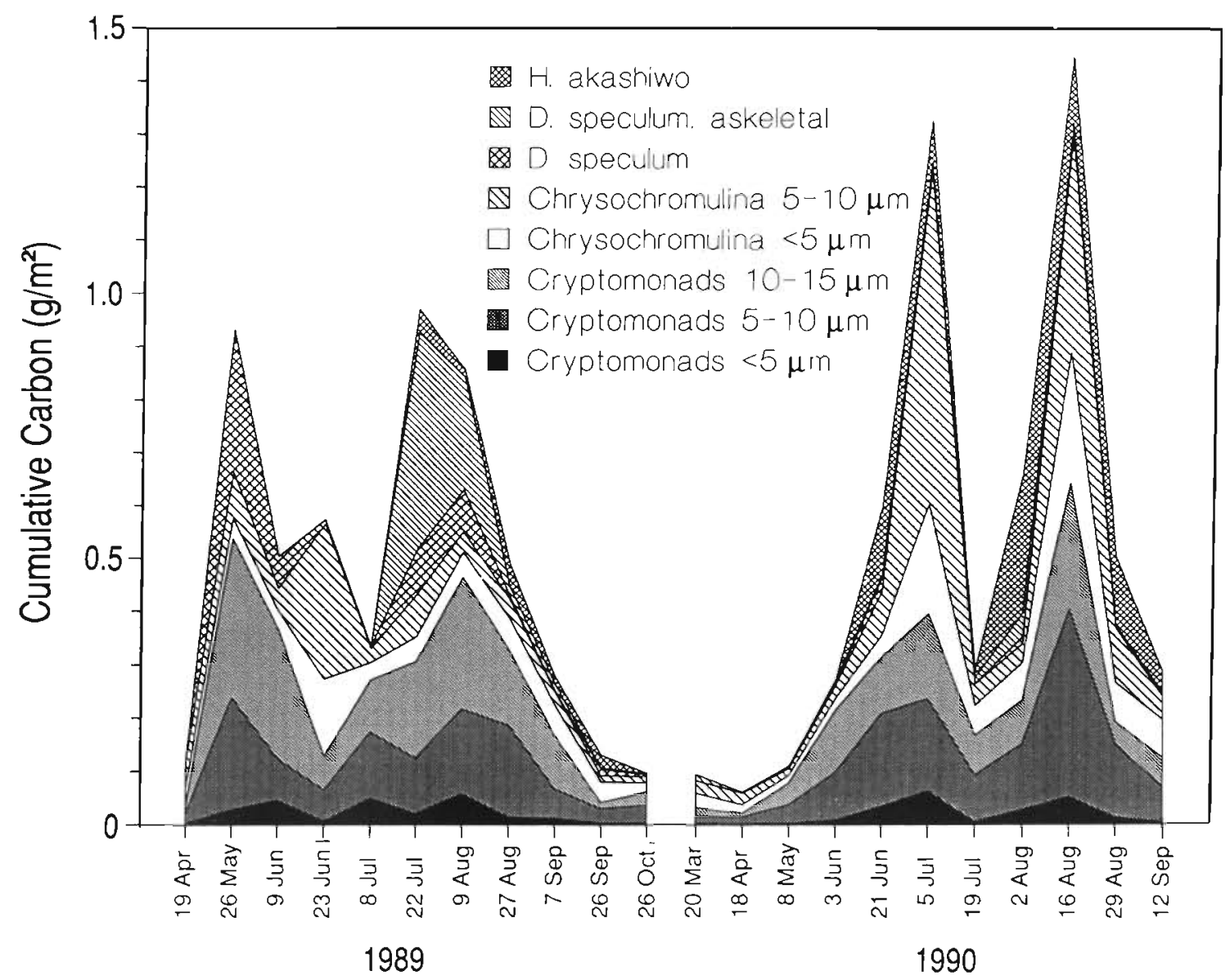

Fig. 12. Cumulative biomass $\left(\mathrm{g} \mathrm{C} \mathrm{m}^{-2}\right)$ time series of the 8 most dominant photosynthetic nano- and microflagellates in the Sechelt Inlet system from April 1989 to September 1990. H.: Heterosigma; D : Dictyocha

there was a notable absence of groups such as coccolithophorids which make incursions into outer Norwegian fjords (Braarud et al. 1974. Braarud 1975. Eilertsen et al. 1981). Low recorded numbers of coccolithophorids, however, may be due to the fact that, because coccoliths dissolve in acidic Lugol's (Throndsen 1978), these flagellates were perhaps overlooked.

\section{Nitrogen : phosphorus ratios}

A balanced marine system should contain 16 atoms of nitrogen for every atom of phosphorus (Redfield et al. 1963). Oligotrophic marine waters tend to have high $\mathrm{N}$ : $\mathrm{P}$ ratios, indicating P-limitation, while eutrophic waters are more $\mathrm{N}$-limited with low $\mathrm{N}: \mathrm{P}$ ratios (Codispoti 1989). It has been suggested that waters in British Columbian inlets are atypical of most of the ocean (Codispoti 1989) due to substantial terrestrial input and high denitrification (cf. Smethie 1987). All stations within the Sechelt Inlet complex exhibited lower than expected $\mathrm{N}: \mathrm{P}$ ratios $\left[\left(\mathrm{NO}_{3}+\mathrm{NO}_{2}+\mathrm{NH}_{4}\right)\right.$ :
$\mathrm{PO}_{4}$ ], ranging from 8.2 to 9.2 in the upper $21 \mathrm{~m}$ and over the $2 \frac{1}{2}$ year study period. These results differ from those of Smethie (1987) who found that the Jervis Inlet complex (including Sechelt and Narrows Inlets) had an $\mathrm{N}$ : P ratio of 11.1 to 11.7 . There are 2 possible reasons for the discrepancy. First, Smethie's ratios were determined over summer periods while ours incorporate data from year-round. Secondly, data from Jervis Inlet strongly influenced the slope of Smethie's correlation line, steepening it. His data for Narrows and Sechelt Inlets appear to support lower N : P ratios closer to ours.

On average, marine species studied in the laboratory yield an N:P ratio of 16 (Sakshaug \& Olsen 1986). Whether a plankter is $N$ - or P-limited will be species specific because each species has a different N : P optimum ratio with respect to cellular requirements (Rhee 1978, Sakshaug et al. 1983). These requirements also change depending on the nutrient regime (e.g. saturation versus subsistence). Based on Sakshaug \& Andresen's (1986) work, Sakshaug et al. (1983) determined that at nutrient saturation and optimal irradiances the N:P optimum ratio is 8.1 for Skeletonema 


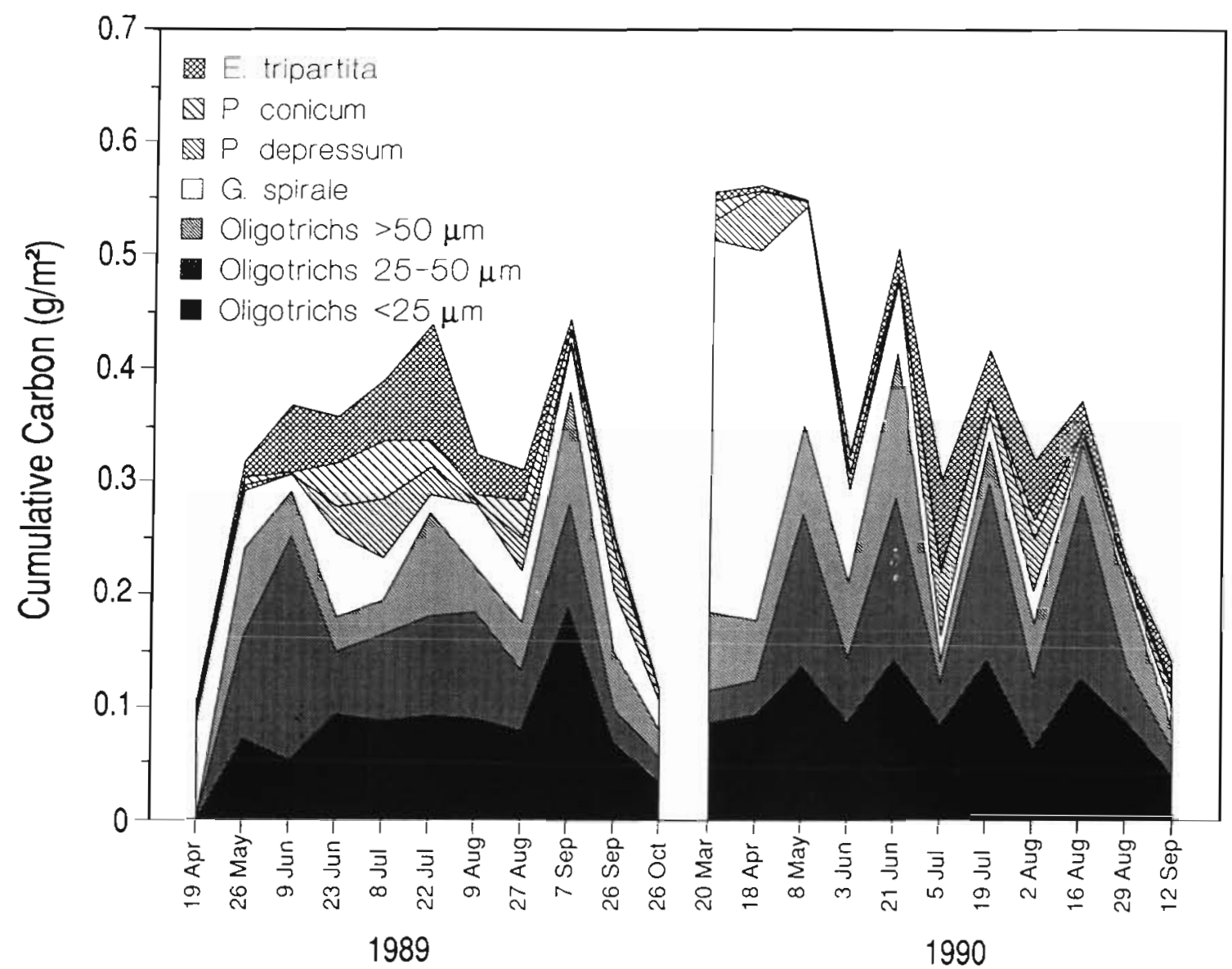

Fig. 13. Cumulative biomass $\left(\mathrm{g} \mathrm{C} \mathrm{m}^{-2}\right.$ ) time series of the 7 most dominant heterotrophic microzooplankton in the Sechelt Inlet system from April 1989 to September 1990. E.: Ebria; P.. Protoperidinium; G. Gyrodinium

costatum. S. costatum requires a greater proportion of phosphate, presumably because it has a high ATP content (Sakshaug \& Andresen 1986) associated with a rapid growth rate. In contrast, the optimum ratio for Thalassiosira pseudonana and $T$. gravida was estimated to be 14 (Hegseth \& Sakshaug 1983). In Sechelt Inlet the surface water $(0-3 \mathrm{~m}) \mathrm{N}: \mathrm{P}$ ratio over time fluctuated around 8 (Fig. 5) and often exceeded this value, especially at the mouth (Stns 1 and 2), suggesting that in surface waters $S$. costatum was more often potentially limited by phosphorus than were other species. It is evident from this figure that higher $N$ : P ratios often immediately followed peaks in $S$. costatum biomass. It is a matter of speculation whether the growth of this diatom was limited by phosphorus or simply drove the ratio up due to its greater need for phosphorus compared to other diatoms. Whether $S$. costatum experiences P-limitation is complicated by other factors such as its ability to store high levels of phosphate under $\mathrm{N}$ stress (Miyata et al. 1986). However, it is interesting to note that the $\mathrm{N}$ : $\mathrm{P}$ ratio for the entire Sechelt Inlet system in the upper $21 \mathrm{~m}$ was
8.3, suggesting that its waters provided an optimal nutrient environment for the growth of this diatom. Indeed S. costatum was often dominant, accounting for a significant proportion of the biomass. A question which arises: can the dominance of this species determine ambient nutrient ratios or does $S$. costatum simply respond to optimal nutrient conditions created by some other force?

The Sechelt Inlet complex yielded a $\mathrm{NO}_{3}: \mathrm{PO}_{4}$ ratio of 8.2 while adjacent Jervis Inlet yielded 11.9 (Fig. 6). The latter value is very close to those observed by Smethie (1987). Saanich Inlet (on the southeastern tip of Vancouver Island) experienced a $\mathrm{NO}_{3}: \mathrm{PO}_{4}$ ratio of 13.0. This inlet has an anoxic bottom which perhaps lowers $N$ : P ratios via denitrification; however, periodic intrusion of oceanic water (Herlinveaux 1962) probably has a greater effect on the ratio. It is interesting to note that the $\mathrm{NO}_{3}: \mathrm{PO}_{4}$ ratio decreased from the inlet of greatest exposure to oceanic influence (Saanich Inlet) to that least exposed (Sechelt Inlet). Connecting Saanich Inlet to Jervis Inlet is the southern Strait of Georgia which is greatly influenced by the Fraser 


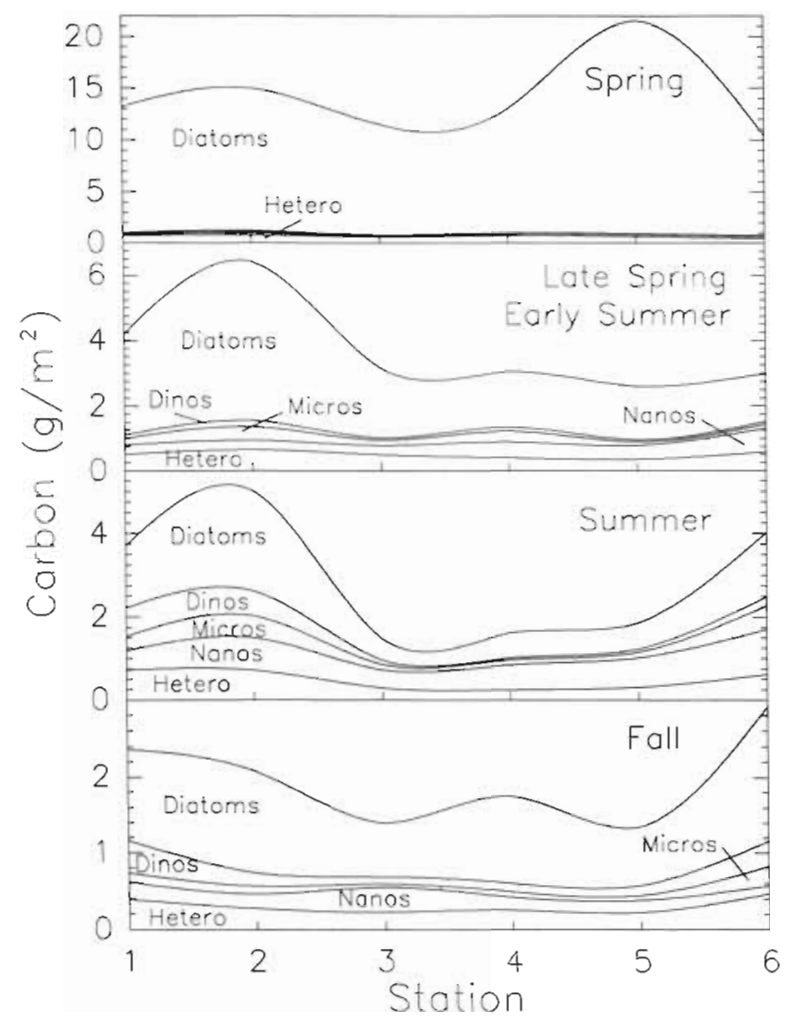

Fig. 14. Stylized distribution of cumulative mean areal biomass $\left(\mathrm{g} \mathrm{C} \mathrm{m}^{-2}\right)$ of diatoms, photosynthetic dino-, micro-, and nanoflagellates, and heterotrophic zooplankton (nano- and micro-) along a transect from Stns 1 to 6 assuming no smallscale patchiness. Spring bloom: March 1990; late spring, early summer: mean of April to June 1989-1990; summer: mean of July to August 1989-1990; fall: mean of September to October $1989-1990$

River, especially during the freshet (LeBlond 1983). This region had a $\mathrm{NO}_{3}: \mathrm{PO}_{4}$ ratio of 9.9 which does not fit the pattern described above. However, the magnıtude of freshwater runoff is so great in this region that one should expect an effect on the N:P ratio by the river water (which tends to have $\mathrm{N}: \mathrm{P}$ ratios less than 7 , calculated from Harrison et al. 1991).

\section{Spring bloom}

The spring bloom successional sequence in British Columbia coastal waters generally follows the trend: Thalassiosira spp. $\rightarrow$ Skeletonema costatum $\rightarrow$ Chaetoceros spp. (Harrison et al. 1983, Sancetta 1989). This trend holds true for other temperate regions (Hasle \& Smayda 1960, Karentz \& Smayda 1984). In Sechelt Inlet $S$. costatum and $T$. nordenskioeldil codominated the biomass in March, although the former far exceeded other species in cell numbers. Perhaps we missed a period when $T$. nordenskioeldii was domi-

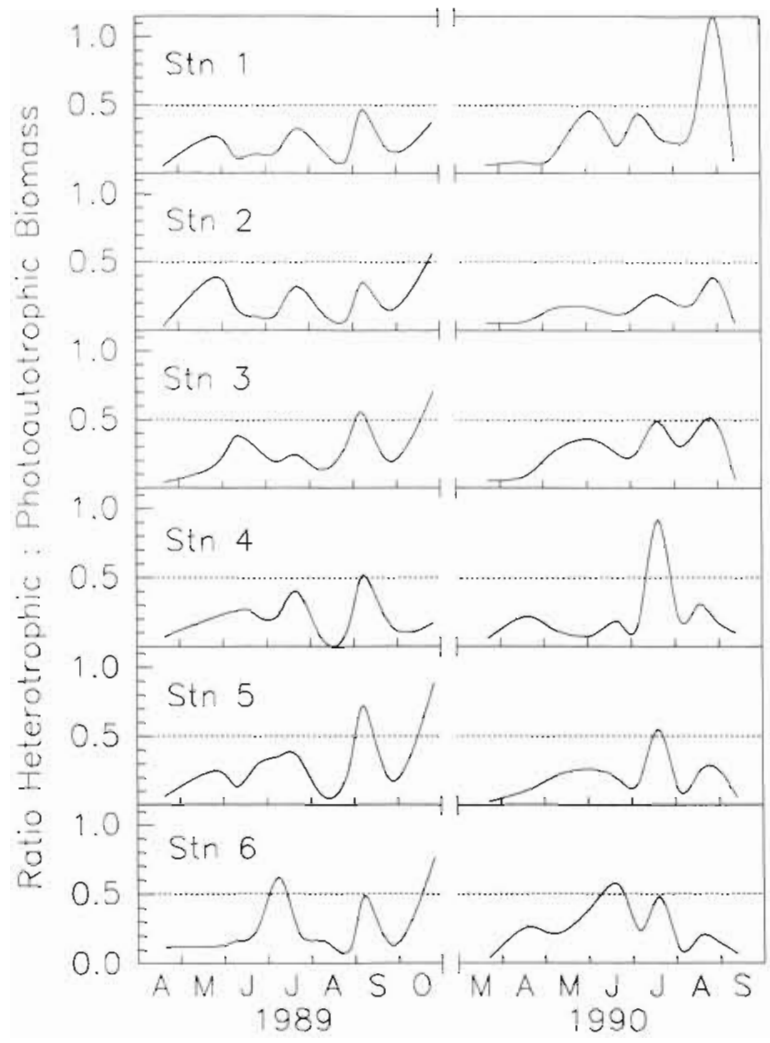

Fig. 15. Ratio of heterotrophic:photoautotrophic biomass at each station from April 1989 to September 1990. Dashed line indicates that the heterotrophic biomass is $50 \%$ of the photoautotrophic biomass

nant. Karentz \& Smayda (1984) also found that these 2 species typically dominated the spring bloom in Narragansett Bay. By April the relative contribution of $S$. costatum in the Sechelt system increased though its biomass decreased.

The spring bloom in Sechelt Inlet (see Fig. 7A) presumably occurred in response to a light regime created by longer photoperiods, higher irradiances, and stratification $\left(\sigma_{t}\right.$ was determined almost entirely by salinity at this time). The restricted depth of mixing suggested by Fig. 7B would have increased the mean light levels for the mixed layer. Stratification was probably the key factor allowing the spring bloom to occur early. Judging by the chlorophyll profile of 1989 (not presented) the bloom eventually extends throughout the system, and there is a net export of diatoms through Skookumchuk Narrows to Jervis Inlet (based on flood/ ebb tide plankton data, Project 88P-1, Water Management Branch, Victoria, B.C.).

On the southern British Columbian coast small sheltered inlets experience the earliest blooming (Gilmartin 1964, Haigh 1988). In the less sheltered southern Strait of Georgia the spring bloom is delayed until April (Stockner et al. 1979, Harrison et al. 1983) 
due to wind-induced turbulence. Further north in the Strait of Georgia, where stratification due to salinity is less significant, the spring bloom may even be suppressed by winds (Haigh \& Taylor 1991). Plankton succession on the outer coast typically lags that in the Strait by $1 \mathrm{mo}$. A chief determining force of the timing of the spring bloom on the southern British Columbian coast is exposure to wind (St. John et al. 1993). The mechanism determining species succession, however, is unknown. Thalassiosira nordenskioeldii is one of the first major diatoms to bloom (often with $T$. aestivalis) in this region. Its growth rate is faster than those of other diatoms at low temperatures and low irradiances (Baars 1982) which gives it a competitive advantage. Skeletonema costatum takes over once light levels exceed a critical level (Hegseth \& Sakshaug 1983). We suspect that the shift from $S$. costatum to Chaetoceros spp. is facilitated by macrozooplankton grazing based on evidence that Chaetoceros is not an optimal food source (Harvey 1937, Parsons et al. 1967, Parsons \& LeBrasseur 1969), perhaps due to the presence of siliceous setae.

The heterotroph Gyrodinium spirale was the major contributor to dinoflagellate biomass during the spring bloom in Sechelt Inlet even though it is not known to consume Skeletonema spp. or Thalassiosira spp. This temporal trend agrees with other observations in the Kiel Bight (Smetacek 1981), Gulf of Maine (Montagnes 1986), and the northern Strait of Georgia (Haigh \& Taylor 1991). Smetacek (1981) observed ingested Nitzschia seriata cells within a few Gyrodinium, and Biecheler (1936) documented the capture and ingestion of a naked oligotrichous ciliate and small dinoflagellates by another heterotrophic species of Gyrodinium. One of us (R.H.) has observed medium-sized fusiform Gyrodinium species with ingested $S$. costatum. The larger $G$. spirale is most likely a grazer on nanoflagellates and perhaps was the reason for the latter's low biomass during the spring bloom.

Immediately following the spring bloom the photosynthetic dinoflagellate Heterocapsa triquetra became an important contributor to dinoflagellate biomass. At Jericho Pier, English Bay, Vancouver, this dinoflagellate first appears in late April, early May (data from the Jericho Plankton Monitoring Program, Dept. of Oceanography, Univ. of British Columbia), and usually becomes one of the dominant species by mid- to lateJune. H. triquetra was one of the dominants of inner Narrows Inlet in early June 1989 (Sutherland 1991). This area proved to be a favourable site for $H$. triquetra within the Sechelt system, along with other flagellates, possibly due to the anoxic bottom of inner Narrows Inlet. Anoxic sediments are known to stimulate flagellate growth via the release of sulphides (Iizuka \& Nakashima 1975) which also act to chelate inhibitory metals such as copper (Iizuka \& Irie 1969). Perhaps there was also a retention mechanism at work similar to that found by Anderson \& Stolzenbach (1985) who reported that $H$. triquetra migrated downwards during the ebb tide in an embayment and was not flushed out in surface brackish waters.

\section{Summer stratification}

By August the surface waters were depleted of nitrate down to $5 \mathrm{~m}$ due to thermal stratification. Nanoplankton, chiefly cryptomonads and Chrysochromulina spp., became dominant in the upper water column during the summer months. Early and late summer experienced peaks in nanoflagellate biomass, with cryptomonads being a regular component. In 1989 the peaks were additionally composed of the silicoflagellate Dictyocha speculum whereas in 1990 Chrysochromulina spp. and Heterosigma carterae accompanied the cryptomonads. Because the 1989 early summer peak followed a period of storm activity (May), we suspect that Chrysochromulina species would have normally co-dominated but were replaced by silicoflagellates. During the late summer peak in 1989, the askeletal form of $D$. speculum bloomed. This form has been linked to fish mortality (Thomsen \& Moestrup 1985) and can occur during silicate depletion (Jochem \& Babenerd 1989). The latter authors attributed the recurrence of this flagellate to the eutrophication of Kiel Bight (Germany), but we see no evidence of eutrophication in the Sechelt Inlet system (except perhaps a localized nutrient loading in Porpoise Bay) and can only suggest that the large diatom bloom of 1989 stripped much of the available silicate from the euphotic zone, setting the nutrient regime off balance for the summer.

The chief summer dinoflagellate species in Sechelt Inlet were Goniodoma pseudogonyaulax, Protoceratium reticulatum, and Ceratium fusus, all of which regularly co-occur in British Columbian waters, especially during the latter part of summer. Both Sechelt Inlet and Norwegian fjords (especially those of the south; Eilertsen et al. 1981) experience periods when dinoflagellates comprise a large portion of total biomass. We suspect that dinoflagellate seed beds occur in Narrows Inlet and Porpoise Bay. There was also advection of dinoflagellates from Jervis Inlet, as reported for the Alexandrium catenella bloom in 1989 (F.J R. Taylor et al. unpubl.). Introduction of plankton populations through Skookumchuk Narrows during summer was a regular phenomenon (supported by flood/ebb tide plankton data, Project 88P-1, Water Management Branch, Victoria, BC). Once advected into the system population growth appeared to be 
stimulated by mixing of water from Narrows Inlet. The waters of inner Narrows Inlet overlie an anoxic bottom, a situation known to have a stimulatory effect on flagellate growth (Iizuka \& Nakashima 1975). This coupled with the injection of nutrients via the Skookumchuck tidal jet lead to high plankton growth. The effect was most pronounced during the midsummer regime of nutrient impoverishment (Fig. 14).

Despite extensive periods of very low nitrate throughout most of the system (Fig. 4B), the nanoflagellates were capable of maintaining at least their background level and at times increased their biomass an order of magnitude (to $10^{6} \mu \mathrm{g} \mathrm{C} \mathrm{m}^{-2}$ ). This may be due to recycled nitrogen (Paasche \& Kristiansen 1982a, Furnas et al. 1986). Furnas et al. (1986) contend that microheterotrophs supply most of the recycled nitrogen in coastal waters (and probably most of the recycled phosphorus; Harrison 1983). Ammonium becomes the dominant dissolved nitrogen form in summer (Paasche \& Kristiansen 1982b). Our data produced significant but dubious correlations between ammonium and various ciliates. Potential sources of ammonium are probably statistically unpredictable due to factors such as the rapid recycling of this nutrient.

\section{Heterotrophic protistan biomass}

There were times, during 1989 and 1990, when nano- and microheterotrophic biomass was greater than $50 \%$ of the photoautotrophic biomass. In marine ecosystems the ecological efficiency between herbivores and phototrophs is $20 \%$ (Parsons et al. 1984c), although there is probably greater efficiency amongst the nano- and micro-components of the planktonic food web. Our protistan biomass ratio fluctuated between 0.03 and 1.16 , the latter value being comparable to Sorokin's (1977) ratio of protozoan: phytoplankton biomass of 1.04. The higher ratios in Sechelt Inlet were perhaps indicative of periods when grazers had overtaken their prey. Also, heterotrophs may have been using particulate organic matter resulting from the decomposition of blooms (Sorokin 1977). We expect these high ratios would not be maintained for long unless there were significant mixotrophy. Ciliates are known to sequester chloroplasts of their prey (Blackbourn et al. 1973, Laval-Peuto \& Rassoulzadegan 1988) and have been shown to contribute significantly to primary production (Stoecker et al. 1987. Stoecker 1991).

Periods when protistan heterotrophs comprised a large proportion of the total biomass occurred during the summer when nutrient limitation had favoured populations of nanoplankton which, in turn, were being grazed by ciliates. D. J. S. Montagnes et al. (unpubl.) explore this further, but briefly, ciliates have growth rates ( 2 to 3 doublings $\mathrm{d}^{-1}$ ) comparable to or greater than their prey so that conceivably they could respond immediately to any increase in the latter's productivity. The other time period when heterotrophic biomass began to approach that of the photoautotrophs was toward late fall after the fall bloom of diatoms. During the winter we would expect that the ratio might be more constant due to less fluctuation in primary production.

\section{SUMMARY}

The Sechelt Inlet complex is a small fjord compared to others on the British Columbia coast and is effectively isolated from oceanic influence, as indicated by the low $N$ : P ratio of 8.3 . Despite its modest size, the complex provides various physical environments, leading to regional differences in plankton production. Generally biomass was greatest at the 2 extremes of Sechelt Inlet and decreased from the time of the spring bloom to the fall period.

The spring bloom started early (March) due to stratification, created by fresh water input from Salmon Inlet, and the sheltered nature of the fjord. Highest biomass at this time occurred near the junction of Salmon and Sechelt Inlets. The species composition of the bloom was similar throughout the system and was dominated by Skeletonema costatum and Thalassiosira nordenskioeldii. The predominance of $S$. costatum was suggested to be linked to the low seawater $\mathrm{N}$ : P ratio: either this diatom caused a reduction in the $\mathrm{N}$ : $\mathrm{P}$ ratio by its growth or the low $\mathrm{N}$ : P ratio provided an optimal nutrient environment. During the spring bloom there was a net export of plankton out of the system.

Once the upper waters of the complex became nutrient-depleted 2 regional forces stimulated plankton production. The first was injection of nutrients via the Skookumchuk tidal jet by mixing and entrainment. The effect of the jet was most pronounced at the junction of Narrows and Sechelt Inlets. This region also received water from inner Narrows Inlet which periodically has an anoxic bottom. Conceivably, the waters of inner Narrows Inlet contained factors such as sulphides which stimulate flagellate growth. The combining of these 2 nutrient sources created a regime in outer Narrows Inlet conducive to the enhancement of all groups during the period of greatest nutrient stress

The second regional effect occurred in the Porpoise Bay area where biomass was stimulated during periods of nutrient stress. This area overlies a shallow shelf with a minor sill which possibly enhanced nutrient flux into the upper waters during tidal and wind mixing. Also, septic tank seepage from the town of Sechelt, located on the southern end of the inlet, may have stimulated production. 
The ratio of heterotrophic: photoautotrophic protistan biomass occasionally exceeded $50 \%$ and ranged from 0.03 to 1.16 , which is probably typical for temperate waters. Ciliates accounted for the majority of the heterotrophic biomass and were most abundant during the summer when nanoflagellates were dominant. These microheterotrophs elevated the ratio by 2 possible mechanisms: high grazing rates coupled with fast doubling times (to be explored in a subsequent paper) and potential mixotrophy.

Acknowledgements. This research was funded, in part, by NSERC grant A6137, with additional contributions from the British Columbia Ministry of Environment. We wish to thank H. MacLean, P. O'Hara, J. Ramirez, C. Leonard, B. Fairfield, S. Lu, R. Johnson, M. Sterling, R. Pederson, L. Lee, and B. Bapte for their help in the field and/or laboratory.

\section{LITERATURE CITED}

Anderson, D. M., Stolzenbach, K. D. (1985). Selective retention of two dinoflagellates in a well-mixed estuarine embayment: the importance of diel vertical migration and surface avoidance. Mar. Ecol. Prog. Ser. 25: 39-50

Anon. (1989). 1989 Summary of paralytic shellfish toxicity records in the Pacific region. Canadian Dept Fisheries \& Oceans Inspection and Special Services Branch, Burnaby

Baars, J. W. M. (1982). Autecological investigation on marine diatoms. 3. Thalassiosira nordenskioeldii and Chaetoceros diadema. Mar. Biol. 68: 343-350

Biecheler, B. (1936). Observation de la capture et de la digestion des proies chez un Peridinien vert. C. r. Séanc. Soc Biol. 122: 1173-1175

Blackbourn, D. J., Taylor, F. J R., Blackbourn, J. (1973). Foreign organelle retention by ciliates. J. Protozool. 20: $286-288$

Braarud, T (1975). The natural history of Hardangerfjord. 12. The late summer water exchange in 1956, its affect upon phytoplankton and phosphate distribution, and the introduction of an offshore population into the fjord in June, 1956. Sarsia 58: 9-30

Braarud, T., Föyn Hofsvang, B., Hjelmfoss, P., Overland, A A.-K. (1974). The natural history of the Hardangerfjord. 10. The phytoplankton in 1955-56. The quantitative phytoplankton cycle in the fjord waters and in the offshore coastal waters. Sarsia 55: 63-98

Buchanan, R. J. (1966). A study of the species composition and ecology of the protoplankton of a British Columbia inlet. Ph.D thesis, Univ. of British Columbia

Campbell, P. H. (1973). Studies on brackish water phytoplankton. I. The phytoplankton of Gales Creek with emphasis on the taxonomy and ecology of estuarine phytoflagellates. Ph.D. thesis, Univ of North Carolina

Cattell, S. A. (1969). Dinoflagellates and vitamin $B_{12}$ in the Strait of Georgia, British Columbia. Ph.D. thesis, Univ. of British Columbia

Clifford, P. J., Harrison, P. J., Yin, K. St. John, M. A., Goldblatt, R. H. (1991). Plankton production and nutrient dynamics in the Fraser River plume, 1990. Manuscr Rep. No. 58, Dept of Oceanography, Univ. of Britush Columbia

Codispoti, L. A. (1989). Phosphorus vs. nitrogen limitation of new and export production. In: Berger, W. H., Smetacek,
V. S., Wefer, G. (eds.) Productivity of the ocean: present and past. John Wiley \& Sons Ltd., Chichester, p. 377-394

Cupp. E. E. (1943). Marine plankton diatoms of the west coast of North America. Univ. of California Press, Berkeley

Dodge, J. D. (1982). Marine dinoflagellates of the British Isles. Her Majesty's Stationery Office, London

Eilertsen, H. C., Schei, B., Taasen, J. P. (1981). Investigations on the plankton community of Balsfjorden, Northern Norway. The phytoplankton 1976-1978. Abundance, species composition, and succession. Sarsia 66: 129-141

Eppley, R. W., Rogers, J. N., McCarthy, J. J. (1969). Halfsaturation constants for uptake of nitrate and ammonia by marine phytoplankton. Limnol. Oceanogr. 14: 912-920

Furnas, M. J., Smayda, T J., Deason, E. A. (1986). Nitrogen dynamics in lower Narragansett Bay. II. Phytoplankton uptake, depletion rates of nitrogenous nutrient pools, and estimates of ecosystem remineralization. J. Plankton Res. 8: $755-769$

Gaines, G., Taylor, F. J. R. (1984). Extracellular digestion in marine dinoflagellates. J. Plankton Res. 6: 1057-1061

Gaines, G., Taylor, F. J. R. (1985). An exploratory analysis of PSP patterns in British Columbia: 1942-1984. In: Anderson, D. M., White, A. W., Baden, D. G. (eds.) Proc. 3rd int. Conf. on Toxic Dinoflageliate Blooms. Elsevier Scientific Publ. Co., New York, p. 439-444

Geider, R. J. (1988). Abundances of autotrophic and heterotrophic nanoplankton and the size distribution of microbial biomass in the southwestern North Sea in October 1986. J. exp. mar. Biol. Ecol. 123: 127-145

Gilmartin, M. (1964). The primary production of a British Columbia fjord. J. Fish. Res. Bd Can. 21: 505-538

Goldberg, E. D., Walker, T J., Whisenand, A. (1951). Phosphate utilization by diatoms. Biol. Bull. 101: 274-284

Gormican, S. J. (1989). Water circulation, dissolved oxygen, and ammonia concentrations in fish net-cages. M.Sc. thesis, Univ. of British Columbia

Haigh, R. (1988). Environmental and biological data, northern Strait of Georgia and Malaspina complex. Manuscr. Rep. No. 49, March 1988, Univ. of British Columbia, Dept of Oceanography

Haigh, R., Taylor, F. J. R. (1991). Mosaicism of microplankton communities in the northern Strait of Georgia, British Columbia. Mar. Biol. 110: 301-314

Harrison, P. J., Clifford, P. J., Cochlan, W. P., Yin, K., St. John, M. A., Thompson. P. A., Sibbald, M. J., Albright, L. J (1991). Nutrient and plankton dynamics in the Fraser River plume, Strait of Georgia, British Columbia. Mar Ecol. Prog. Ser. 70: 291-304

Harrison, P. J., Fulton, J. D., Taylor, F. J. R., Parsons, T. R. (1983). Review of the biological oceanography of the Strait of Georgia: pelagic environment. Can. J. Fish. Aquat. Sci. 40: $1064-1094$

Harrison, W. G. (1983). Uptake and recycling of soluble reactive phosphorus by marine microplankton. Mar. Ecol. Prog. Ser. 10: 127-135

Harvey, H. W. (1937). Notes on selective feeding by Calanus. J. mar. biol. Ass. U.K. 22: $97-100$

Hasle, G. R. (1978). Using the inverted microscope. In: Sournia, A. (ed.) Phytoplankton manual. Monographs on oceanographic methodology 6. UNESCO, Paris, p. 191-196

Hasle, G. R., Smayda, T. J. (1960). The annual phytoplankton cycle at Drobak, Oslofjord. Nytt. Mag. Bot. 8: 53-75

Hegseth, E. N. Sakshaug, E. (1983). Seasonal variation in light- and temperature-dependent growth of marine planktonic diatoms in situ dialysis cultures in Trondheimsfjord, Norway $\left(63^{\circ} \mathrm{N}\right)$. J. exp. mar. Biol Ecol. 67 : $199-220$ 
Hendey, N. I. (1964). An introductory account of the smaller algae of British coastal waters. Part V: Bacillariophyceae (Diatoms). Her Majesty's Stationery Office, London

Herlinveaux, R. H. (1962). Oceanography of Saanich Inlet in Vancouver Island, British Columbia. J. Fish. Res. Bd Can. 19: $1-37$

lizuka, S., Irie, H. (1969). Anoxic status of bottom waters and occurrences of Gymnodinium red water in Omura Bay. Bull. Plankton Soc. Jpn 16: 99-115

lizuka, S., Nakashima, T (1975). Response of red tide organisms to sulphide. Bull. Plankton Soc. Jpn 22: 27-32

Jochem, F., Babenerd, B. (1989). Naked Dictyocha speculuma new type of phytoplankton bloom in the Western Baltic. Mar. Biol. 103: 373-379

Karentz, D., Smayda, T. J. (1984). Temperature and seasonal occurrence patterns of 30 dominant phytoplankton species in Narragansett Bay over a 22-year period (1959-1980). Mar. Ecol. Prog. Ser. 18: 277-293

Laval-Peuto, M., Rassoulzadegan, F. (1988). Autofluorescence of marine planktonic Oligotrichina and other ciliates. Hydrobiologia 159: 99-110

Lazier, J. R. N. (1963). Some aspects of the oceanographic structure in the Jervis Inlet system. M.Sc. thesis, Univ. of British Columbia

LeBlond, P. H. (1983). The Strait of Georgia: functional anatomy of a coastal sea. Can. J Fish. Aquat. Sci. 40: 1033-1063

Miyata, K. Hattori, A., Ohtsuki, A. (1986). Variation of cellular phosphorus composition of Skeletonema costatum and Heterosigma akashiwo grown in chemostats. Mar Biol. 93: 291-297

Montagnes, D. J S. (1986). The annual cycle of planktonic ciliates in the waters surrounding the Isles of Shoals, Gulf of Maine: estimates of biomass and production. M.Sc. thesis, Univ. of Guelph

Paasche, E., Kristiansen, S. (1982a). Ammonium regeneration by microzooplankton in the Oslofjord. Mar. Biol. 69: 55-63

Paasche. E., Kristiansen, S. (1982b). Nitrogen nutrition of the phytoplankton in the Oslofjord. Estuar. coast. Shelf Sci. 14: $237-249$

Parsons, T. R., Dovey, H. M., Cochlan, W. P., Perry, R. I., Crean, P. B. (1984b). Frontal zone analysis at the mouth of a fjord - Jervis Inlet, British Columbia. Sarsia 69: 133-137

Parsons, T. R., LeBrasseur, R. J. (1969). The availability of food to different trophic levels in the marine food chain. In: Steele, J. H. (ed.) Marine food chains. Oliver and Boyd, Edinburgh, p. 325-343

Parsons, T. R., LeBrasseur, R. J., Fulton, J. D. (1967). Some observations on the dependence of zooplankton grazing on the cell size and concentration of phytoplankton blooms. J. Oceanogr. Soc. Japan 23: 10-17

Parsons, T R., Maita, Y., Lalli, C. M. (1984a). A manual of chemical and biological methods for seawater analysis. Pergamon Press, Oxford

Parsons, T. R., Takahashi, M., Hargrave, B. (1984b). Biological oceanographic processes. Pergamon Press, Oxford

Pasciak, W. J., Gavis, J. (1974). Transport limitation of nutrient uptake in phytoplankton. Limnol. Oceanogr. 19: $881-888$

Pickard, G. L. (1961). Oceanographic features of inlets in the British Columbia mainland coast. J. Fish. Res. Bd Can. 18: 907-999

Putt, M., Stoecker, D. K. (1989). An experimentally determined carbon:volume ratio for marine 'oligotrichous' ciliates from estuarine and coastal waters. Limnol. Oceanogr. 34: 333-355

Redtield, A. C., Ketchum, B. H., Richards, F. A. (1963). The influence of organisms on the composition of seawater. In: Hill, M. N. (ed.) The sea, Vol. 2. Interscience, New York, p. 26-27

Rhee, G.-Y (1978). Effects of N:P atomic ratios and nitrate limitation on algal growth, cell composition, and nitrate uptake. Limnol Oceanogr. 23: 10-25

Rines, J. E. B., Hargraves, P. E. (1988). The Chaetoceros Ehrenberg (Bacillariophyceae) flora of Narragansett Bay, Rhode Island, U.S.A. Bibliotheca Phycologia 79

Sakshaug, E., Andresen, K. (1986). Effect of light regime upon growth rate and chemical composition of a clone of Skeletonema costatum from the Trondheimsfjord, Norway. J. Plankton Res. 8: 619-637

Sakshaug, E., Andresen, K., Myklestad, S., Olsen, Y (1983). Nutrient status of phytoplankton communities in Norwegian waters (marine, brackish, and fresh) as revealed by their chemical composition. J. Plankton Res. 5: $175-196$

Sakshaug, E., Olsen, Y. (1986). Nutrient status of phytoplankton blooms in Norwegian waters and algal strategies for nutrient competition. Can. J Fish. Aquat. Sci. 43: 389-396

Sancetta, C. (1989). Spatial and temporal trends of diatom flux in British Columbian fjords. J. Plankton Res. 11: $503-520$

Schiller, J. (1933). Dinoflagellates (Peridineae). In: Rabenhorst, L. (ed.) Kryptogamen-Flora von Deutschland, Österreich und der Schweiz, 10(3/1). Akademische Verlagsgesellschaft, Leipzig

Schiller, J. (1937). Dinoflagellates (Peridineae). In: Rabenhorst, L. (ed.) Kryptogamen-Flora von Deutschland, Österreich und der Schweiz, 10(3/2). Akademische Verlagsgesellschaft, Leipzig

Smetacek, V. (1981). The annual cycle of protozooplankton in the Kiel Bight. Mar. Biol. 63: 1-11

Smethie, W. M. Jr (1987). Nutrient regeneration in low oxygen fjords. Deep Sea Res. 34: 983-1006

Sorokin, Yu. I. (1977). The heterotrophic phase of plankton succession in the Japan Sea. Mar. Biol. 41: 107-117

St. John, M. A., Marinone, S. G., Stronach, J., Harrison, P. J., Fyfe, J. (1993). Modelling the effects of physical forcing on nutrient fluxes and primary productivity in the Strait of Georgia. Can. J. Fish. Aquat. Sci. in press

Stockner, J. G., Cliff, D. D., Shortreed, K. R. S. (1979). Phytoplankton ecology of the Strait of Georgia. J. Fish. Res. Bd Can. 36: $657-666$

Stoecker, D. K. (1991). Mixotrophy in marine planktonic ciliates: physiological and ecological aspects of plastidretention by oligotrichs. In: Reid, P. C., Turley, C. M., Burkill, P. H. (eds.) Protozoa and their role in marine processes. Springer-Verlag, Berlin, p. 161-179

Stoecker, D. K., Michaels, A. E., Davis, L. H. (1987). Large proportion of marine planktonic ciliates found to contain functional chloroplasts. Nature 326: 790-792

Strathmann, R. R. (1967). Estimating the organic carbon content of phytoplankton from cell volume or plasma valume Limnol. Oceanogr. 12: 411-418

Sutherland, T (1991). Phytoplankton succession and resting stage occurrence in three regions in Sechelt Inlet, British Columbia. M.Sc. thesis, Univ. of British Columbia

Sutherland, T F., Leonard, C., Taylor, F. J. R. (1992). A segmented integrating pipe sampler for profiling the upper water column. J. Plankton Res. 14: 915-923

Taylor, F. J. R. (1992). The taxonomy of harmful marine phytoplankton. Giornale Botanico Italiano 126: 209-219

Taylor, F. J R., Haigh, R., Sutherland, T. F., Ramirez, J. A. (1991). Final report of the harmful algal research project 
in Sechelt Inlet, British Columbia, 1988-1990. Report prepared for the British Columbia Ministry of Environment, Vancouver

Thomas, W. H., Dodson, A. N. (1968). Effects of phosphate concentration on cell division rates and yield of a tropical oceanic diatom. Biol. Bull. 134: 199-208

Thomsen, H. A., Moestrup, O. (1985). Is Distephanus speculum a fish-killer? A report on an unusual algal bloom from Danish coastal waters. Bull. mar. Sci. 37: 778

This article was submitted to the editor
Throndsen, J. (1978). Preservation and storage. In: Sournia, A (ed.) Phytoplankton manual. Monographs on oceanographic methodology 6. UNESCO, Paris, p. 69-74

Throndsen, J. (1988). Cymbomonas Schiller (Prasinophyceae) reinvestigated by light and electron microscopy. Arch. Protistenkd. 136: 327-336

Wood, E. D., Armstrong, F. A. J., Richards, F. A. (1967) Determination of nitrate in seawater by cadmium-copper reduction to nitrite. J. mar. biol. Ass. U.K. 47: 23-31

Manuscript first received: June 22, 1992

Revised version accepted: October 19, 1992 